\title{
Improving water use efficiency of vineyards in semi-arid regions. A review
}

\author{
Hipólito Medrano • Magdalena Tomás • Sebastiá Martorell • \\ José-Mariano Escalona • Alicia Pou • Sigfredo Fuentes • \\ Jaume Flexas • Josefina Bota
}

Accepted: 28 November 2014 / Published online: 31 December 2014

(C) INRA and Springer-Verlag France 2014

\begin{abstract}
Water is critical for viticulture sustainability since grape production, quality and economic viability are largely dependent on water availability. The total water consumption of vineyards, 300 to $700 \mathrm{~mm}$, is generally higher than the annual average precipitation in many viticultural areas, which induces a risk for sustainability of vineyards. Improving vineyard water use efficiency (WUE) is therefore crucial for a sustainable viticulture industry in semi-arid regions. Increased sustainability of water resources for vineyards can be achieved using both agronomical technology and cultivar selection. Here, we review advances in grapevine water use efficiency related to changes in agronomical practices and genetic improvements. Agronomical practices focus on increasing green water use by increasing soil water storage capacity, reducing direct soil water loss, or limiting early transpiration losses. Cover crops for semi-arid areas show a favorable effect, but careful management is needed to avoid excessive water consumption by the cover crop. Canopy management practices to reduce excessive water use are also
\end{abstract}

Hipólito Medrano and Josefina Bota contributed equally to the present work.

H. Medrano $(\varangle) \cdot$ M. Tomás $\cdot S$. Martorell · J.-M. Escalona •

J. Flexas $\cdot$ J. Bota

Research Group on Plant Biology under Mediterranean Conditions, Department of Biology, UIB-Universitat de les Illes Balears, Carretera de Valldemossa Km 7.5, 07122 Palma de Mallorca, Spain e-mail: hipolito.medrano@uib.es

\section{A. Pou}

Institute of Life Science, Catholic University of Louvain, Place de l’Université 1, 1348 Louvain-la-Neuve, Belgium

\section{S. Fuentes}

Department of Agriculture and Food Systems. Faculty of Veterinary and Agricultural Sciences, The University of Melbourne, Parkville, Victoria 3010, Australia analyzed. This is a genetic based review focused on identifying cultivars with higher WUE.

Keywords Soil water availability $\cdot$ Irrigation $\cdot$ Drought . Genotypes $\cdot$ Carbon balance $\cdot$ Water economy $\cdot \delta^{13} \mathrm{C}$

\begin{tabular}{ll}
\multicolumn{2}{l}{ Abbreviations } \\
$\mathrm{A}_{\mathrm{N}}$ & Net leaf photosynthesis \\
$\mathrm{g}_{\mathrm{s}}$ & Stomatal conductance \\
WUE & Water use efficiency \\
WUEi & Intrinsic water use efficiency $\left(\mathrm{A}_{\left.\mathrm{N} / \mathrm{g}_{\mathrm{s}}\right)}\right.$ \\
WUEc & Crop water use efficiency \\
WFP & Water foot print \\
ETc. & Crop evapotranspiration \\
$\delta^{13} \mathrm{C}$ & Carbon isotope discrimination
\end{tabular}

Contents

1. General introduction

2. Improving WUE by agronomic practices

2.1 Maximizing green water use

2.1.1 Mulching

2.1.2 Cover crops

2.2 Canopy management

2.3 Irrigation strategies and WUE

2.3.1 Deficit irrigation, partial root irrigation, or partial root drying

2.3.2 Effects on plant physiology

2.3.3 Effects on yield, grape, and wine quality

3. Genetic variability of water use efficiency

3.1 Cultivar influence in WUE

3.2 Rootstock influence in WUE and rootstock-scion interactions

4. Concluding remarks 


\section{General introduction}

Sustainability in agriculture is an important goal for many farmers and agronomists. This is supported by a wide range of evidence showing the necessity and convenience of sustainable practices in agricultural lands for long-time exploitation of non-renewable natural resources, such as water and soil. This concern is commonly presented in current literature, which identifies water use efficiency as a general goal for different crops from the farm to regions and country scales (Deng et al. 2006; Geerts and Raes 2009; Katerji et al. 2008; Morison et al. 2008). Considering these society concerns, there is also a growing tendency to exhibit greener and cleaner food production. For viticulture, sustainability is becoming a serious concern due to the high extension of the crop in many different climatic conditions and high inputs required. Furthermore, the carbon and water footprint labels are having an increased importance within produces and wine trades. This is related to the wider positive appreciation of a minimal carbon and water footprint of the crop or to the "going greener" concept, which shows a certain salutary interest of grape growers and winemakers related to the whole sustainability of the vineyards and wineries.

Within these concerns, the water issue is the most important for environmental sustainability of viticulture with a $60 \%$ presence in semi-arid areas (Flexas et al. 2010). However, the reduction of pesticide use could be more important in other climates. High water requirements are necessary to complete the growth cycle of grapevines, which coincides with the driest months, making irrigation scheduling and timing critical (Williams and Ayars 2005). In dry areas, water use by irrigation scheduling can be a compromise for environmental sustainability of the crop and sometimes be a competition with other critical human uses (Chaves et al. 2007). Moreover, evaporative demand is expected to increase as a consequence of increased global air temperature (Vicente-Serrano et al. 2014) and intensity of climatic anomalies, such as droughts and heat waves (IPCC 2013; Jones and Vaughan 2010). These effects could only be alleviated with higher transpiration rates to lower leaf temperature. All those circumstances are a prevalent condition for most of the semi-arid regions of grapevine production, as well as most of the "new world" viticulture due to the high irrigation volumes required to obtain a reasonable harvest.

Consequently, the optimization of water use for vineyards, by improving water use efficiency (WUE), is a core subject of interest to secure sustainability in viticulture. In consequence, an important volume of applied and fundamental research has been focused into the exploration of the capacity to optimize grapevine water use. An important part of these researches are related to the evaluation of irrigation timing and schedule by introducing new technologies to reduce water consumption (Chaves et al. 2010; Romero et al. 2010; Sadras 2009;
Williams et al. 2010). Regarding the improvement of genetic capacities to enhance WUE, some works have been focused on the estimation of the genetic variation of grapevine rootstocks or cultivars (Alsina et al. 2007; Satisha et al. 2006; Tomás et al. 2012).

However, most of these researches reflect the increasing social interest and the necessity of optimizing water use by the grapevine crop. Related to this, increasing concerns about the water foot print (WFP) of grapes and wine production reinforces the importance of water economy as a convenient label for the grapevine fruit and wine industry. To determine WFP, three water categories have been considered: (i) green water, which is water coming from rain/snow or other natural sources directly to the cropped land; (ii) blue water, which is water used for irrigation, and (iii) gray water, related to industrial processes around the winery practices and agronomic practices.

Fortunately, for most of the wine regions, high grape yield is not the main concern for farmers since grape quality is routinely assessed and rewarded. Also, the highest fruit quality is negatively correlated to higher yields (Romero et al. 2013; Williams and Matthews 1990). In summary, it can be said that high-quality yield is generally achieved under suboptimal crop conditions. Therefore, water stress has become a management target to secure high fruit quality and improve sustainability of water use by rewarding crop quality over quantity.

In the present paper, we summarize different ways available to improve the WUE of grapevines on the basis of the WFP classification, thus increasing the green water consumption, reducing the blue water use, and improving genetically the capacity to achieve higher WUE allows the increased sustainability of vineyards. Figure 1 summarizes the different scales to measure WUE in grapevines.

\section{Improving WUE by agronomic practices}

\subsection{Maximizing green water use}

Management of water stored in the soil by accumulation of rainfall is crucial to reduce plant irrigation requirements. The ways to enhance total water availability to the plants can be related to the improved capacity of soils to store water. Improvements in soil physical and chemical structure and properties can be achieved by, for example, adding organic matter and avoiding soil water unnecessary losses, thus reducing direct soil water evaporation by mulching, and increasing water availability to plants with deeper and more extensive root systems (more drought adapted rootstocks).

\subsubsection{Mulching}

Organic mulching is a sustainable agronomic practice widely used to prevent soil erosion and improve general soil 
Fig. 1 Measuring water use efficiency in grapevine at different scales, from leaf to watershed level (adapted from Medrano et al. 2010)
MEASUREMENT LEVELS OF THE GRAPEVINE WATER USE EFFICIENCY

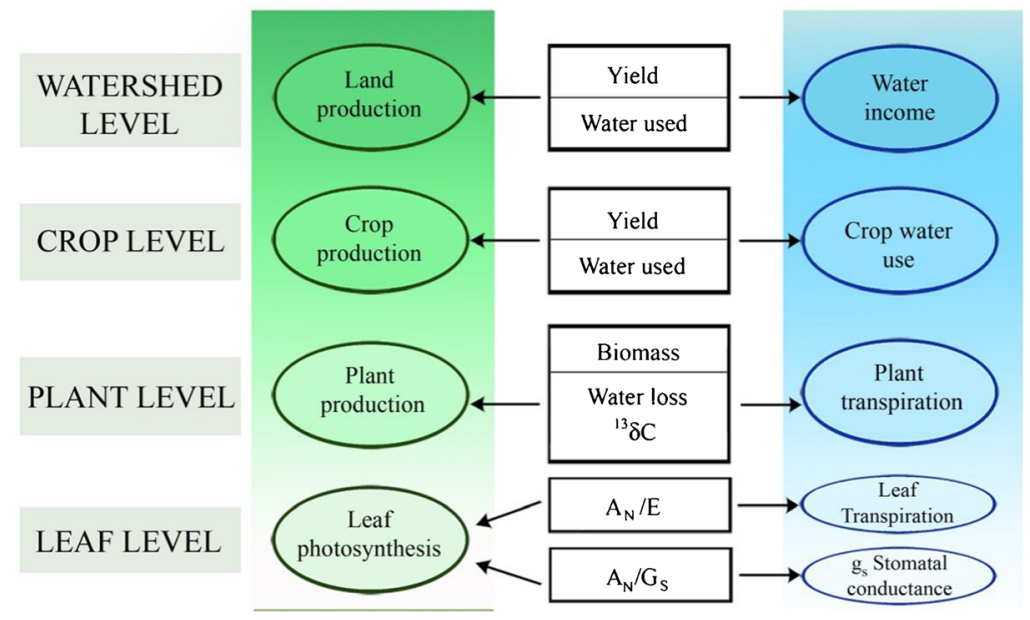

properties. Straw mulch is an easily available and relatively cheap material, but so are crop residues or compost from waste products, which can also be used as mulching material (Fig. 2). Furthermore, besides waste products from other origins, vineyard and winery waste products can be incorporated into mulches.

The reported advantages of mulching in vineyards include the following: (i) nutrient release efficiency and better plant nutrient status, enabling a reduction in fertilizer application (Agnew et al. 2002, 2005; Ross 2010; Nguyen et al. 2013); (ii) weed control, which enables reduction in herbicide application (Elmore et al. 1998; Frederikson et al. 2011; Steinmaus

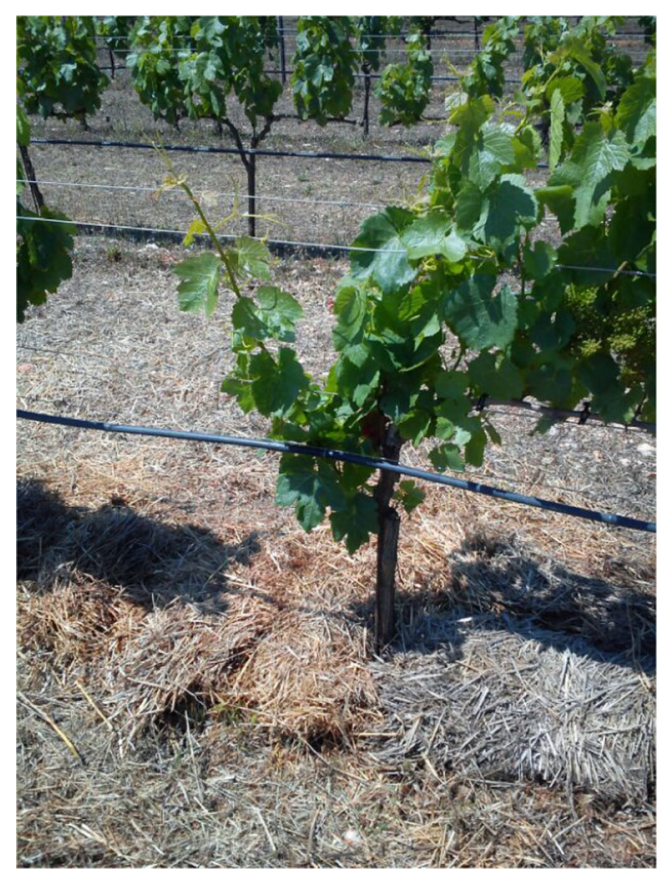

Fig. 2 Straw mulch in young grapevines (University of Balearic Islands, Mallorca, Balearic Islands, Spain) et al. 2008); (iii) prevention of soil erosion by improving soil structure and decrease soil compaction (Agnew et al. 2002; Göblyös et al. 2011; Némethy 2004), and (iv) increasing vineyard biodiversity, which can, in turn, encourage beneficial insects to prevent pests (Huber et al. 2003; Nicholls et al. 2001; Thomson and Hoffmann 2007). A recent review by Guerra and Steenwerth (2012) showed how the use of organic mulches increased yields and reduced pathogen and pest pressure. Furthermore, Nguyen et al. (2013) showed how natural compost mulch increased grape yield with no adverse effects on grape quality. Other studies also reported a higher yield of mulched grapevines compared to other soil management practices (Buckerfield and Webster 2001; Fourie 2011).

So far, the mulching effect on the crop water retention, consumption, and consequently, on the crop water use efficiency (WUEc) has not been widely studied. WUEc can be defined as the ratio between crop production and total water used. Total crop water use includes the amount of water lost directly from the soil, without being used by the plant. The latter occurs through soil evaporation, runoff, and leaching, and, as pointed out by Gregory (2004), it can be avoided or reduced by agronomic practices such as mulching. Similarly, Davies et al. (2011) showed how, by applying mulches, it could affect more directly WUEc as they can modify soil reserves, minimizing soil evaporative losses and consequently improving water soil infiltration. These results are in agreement with some reviews showing how surface residue management or mulching can improve WUEc by reducing soil evaporation and runoff in other crops (Davies et al. 2011; Hatfield et al. 2001).

For grapevines, Pinamonti (1998) reported how compostmulched soils presented better water permeability and water storage capacity and reduced evaporation compared to plastic mulches or bare soil in a Merlot vineyard (showing around $2 \%$ increase of water availability in the soil). Agnew et al. (2002) found that mulches helped to retain soil moisture early 
in the season with moisture levels around $5 \%$ higher under mulch in the upper part of the soil profile $(0-30 \mathrm{~cm})$. In Hungarian vineyards with sandy soils, the most favorable soil moisture was found under straw mulch compared to cover crops or mechanical tillage. On a yearly average, the soil moisture content between $0-60 \mathrm{~cm}$ was $3.4 \%$ higher in the covered soil than in the tilled one. In addition, soil penetration resistance (related to the soil compaction) was reduced by $50 \%$ (Némethy 2004). In a recent study, Zhang et al. (2014) showed interesting results on potted grapevines about improvements of WUEc and yield by applying rice-straw mulch. On the other hand, Nguyen et al. (2013) did not find higher soil water content in compost-mulched grapevines, but presented higher yield. Nevertheless, measurements by our group showed that direct soil evaporation can be up to $20 \%$ of water consumption, so covered soil may result in greater plant water availability (Buckerfield and Webster 2001).

Summarizing, soil management using mulching can be seen as an efficient tool to control soil water loss and therefore improve WUE as can be seen in Table 1, which summarizes the referred literature on the effects of mulching on soil water content. However, there is still a lack of information about the quantification of the contribution of mulching to water savings and WUEc improvements for grapevines. The amount of saved water or reductions in irrigation water requirements are not easy to generalize since the effects of mulching largely varies with soil types, rainfall patterns, and evaporative demands (Jalota et al. 2001). On the other hand, different mulch materials can result in different water holding capacity and evaporative loss variability (Shaw et al. 2005). In this sense, more specific studies in different conditions are necessary to determine the effects of mulches on water conservation by soils, plant WUE, and plant growth.

\subsubsection{Cover crops}

With few exceptions, natural terrestrial ecosystems have a continuous cover of some amount of plant residue on the soil surface, and this residue can have some effects on seedling emergence and succession of vegetation communities (Facelli and Pickett 1991). Cover crops have been largely recommended to extract excessive water and nutrients within the effective root zone of plants, which can induce excessive vigor in grapevines. Nowadays, jointly with mulching, cover crops have been also used to reduce the risk of soil erosion and water runoff and to improve soil fertility and structure, mainly when cash crops are not actively growing (Folorunso et al. 1992a, b; Hartwig and Hoffman 1975; Shanks et al. 1998). However, only a small percentage of farmers are planting cover crops in semi-arid areas due to the disadvantages outweighing the advantages since the positive effects of using cover crops are not always clear and cost effective (Table 2). Although the off-season water used by a cover crop has positive effects in some climates, yield losses associated with water lost by the cover crop are often found in areas with less than $1000 \mathrm{~mm}$ of annual rainfall (Hartwig and Ammon 2002). So, it is necessary to have a complete account of the total and available water holding capacities of the soil and the potential, as well as actual, rooting depths of the crop to advise on the specific results. Furthermore, in order to maximize the potential benefits of specific cover crops and to avoid the undesirable ones, the accurate selection of species and varieties are key points in the decision-making process. For example, under Mediterranean conditions, early senescent and selfseeding or perennial species such as Dactillys sp., Medicago sp., and Trifolium sp., among others, can meet both these objectives by improving soil characteristics and by competing for water resources until mid-spring, helping in this way vigor control for grapevines (Pou et al. 2011).

Table 1 Soil water availability changes in response to cropping practices. Analysis of referred work showing the location, the soil type, variety, type of mulching or cover crop and changes in soil moisture

\begin{tabular}{|c|c|c|c|c|c|}
\hline Reference & Location & Type of soil & Cultivar & Soil management & $\begin{array}{l}\text { Percent of soil water } \\
\text { availability changes }\end{array}$ \\
\hline Pinamonti 1998 & Adige Valley, Italy & $\begin{array}{l}\text { Udorthents, medium } \\
\text { sandy }\end{array}$ & Merlot & Compost mulch & $2 \%$ soil moisture increase \\
\hline Agnew et al. 2002 & $\begin{array}{l}\text { Marlborough, New } \\
\text { Zealand }\end{array}$ & Silty clay & Sauvignon blanc & Compost mulch & $5 \%$ soil moisture increase \\
\hline Némethy 2004 & Szigetcsép, Hungary & Sandy & Not described & Straw mulch & $\begin{array}{l}3.4 \% \text { soil moisture } \\
\text { increase }\end{array}$ \\
\hline Nguyen et al. 2013 & $\begin{array}{l}\text { Marlborough, New } \\
\text { Zealand }\end{array}$ & Silty clay & Merlot & Compost mulch & Null soil moisture increase \\
\hline Wheeler et al. 2005 & Hawke's Bay, New Zeland & sandy-clay-loamy & Cabernet Sauvignon & $\begin{array}{l}\text { Permanent sown } \\
\text { cover crop }\end{array}$ & $7 \%$ soil moisture decrease \\
\hline Gulick et al. 1994 & Parlier, California & fine sandy loam & Thompson seedless & Perennial cover crop & $\begin{array}{l}46 \% \text { soil moisture } \\
\text { decrease }\end{array}$ \\
\hline Gulick et al. 1994 & Parlier, California & fine sandy loam & Thompson seedless & Winter cover crop & $19 \%$ soil moisture decrease \\
\hline
\end{tabular}


Table 2 Comparison of cost and benefits of cover crops for vineyards under climates without water stress in respect to climates with typical summer drought

\begin{tabular}{|c|c|c|c|}
\hline & Benefits & Costs & Recommended cover crops \\
\hline $\begin{array}{l}\text { Rain boundless } \\
\text { climates }\end{array}$ & $\begin{array}{l}\text { - Protects soil from erosion and crusting } \\
\text { - Improves soil fertility and structure } \\
\text { increasing soil water retention capacity } \\
\text { - Regulates vine growth (vigor) and yield by } \\
\text { reducing water availability for the grape }\end{array}$ & $\begin{array}{l}\text { - Cost of establishment and regular } \\
\text { maintenance } \\
\text { - Management of irrigation, fertilization, } \\
\text { and other practices must meet the needs } \\
\text { of both, crop, and cover crop }\end{array}$ & $\begin{array}{l}\text { - Permanent or perennial cover crops of grasses } \\
\text { and/or spontaneous herbs covering all vineyard } \\
\text { surfaces all along the grapevine vegetative growth. } \\
\text { - For deep soils with presumably adequate available } \\
\text { soil moisture, the recommended crop includes } \\
\text { rapid growing grass species. }\end{array}$ \\
\hline $\begin{array}{l}\text { Rain-limited } \\
\text { climates }\end{array}$ & $\begin{array}{l}\text { - Improves soil fertility and biological } \\
\text { activity (mycorrhiza) implicated in water } \\
\text { and nutrients uptake. } \\
\text { - Improves soil water-holding capacity by } \\
\text { decreasing soil mechanical resistance and } \\
\text { increasing water infiltration } \\
\text { - Diminishes direct soil evaporation during } \\
\text { summer } \\
\text { - In deep soils, increases vine root growth } \\
\text { and limits direct competition for water } \\
\text { resources } \\
\text { - Early adjustment of plant leaf area reduces } \\
\text { later water necessities }\end{array}$ & $\begin{array}{l}\text { - Cost of establishment and regular } \\
\text { maintenance } \\
\text { - Competition with vines for water and } \\
\text { nutrients. } \\
\text { - Not recommendable for early vineyard } \\
\text { establishment. }\end{array}$ & $\begin{array}{l}\text { - Non-permanent or annual cover crops with no } \\
\text { growth during summer. } \\
\text { - Partial vineyard coverage (alternating rows } \\
\text { with/without cover crop) } \\
\text { - For shallow soils receiving limited rainfall and } \\
\text { for hillside vineyards, the recommended mix } \\
\text { contains a variety of fescues (Festuca spp.) } \\
\text { - For semi-arid areas a mix of grasses and legume }\end{array}$ \\
\hline
\end{tabular}

A bulk of research has been done aiming to assess the effects of a particular mixture of Mediterranean legumes and grasses as inter-row cover crop to evaluate the impacts on soil structural stability and crop performance. Also, to improve leaf area development, leaf gas exchange, biomass stability, or productivity (Clark 2007; Fourie et al. 2006; Lopes et al. 2004; Monteiro et al. 2008; Teasdale 1996) were evaluated. For grapevines growing in water-limited areas, ground covers can be managed to compete with vines during the early vegetative growth, thus reducing their canopy leaf area and consequently reducing later transpiration losses (Dry and Loveys 1998; Monteiro and Lopes 2007). This management strategy also enhances grape and must quality (Ingels et al. 2005; Pinamonti 1998; Wheeler et al. 2005; Winkler et al. 1974). However, it is important to impose these strategies in a timely fashion to avoid excessive water stress to the plants that could reduce fruit set or cause even premature defoliation. For those areas, cover crops can finally result as disadvantageous when water competition occurs after spring, which could lead to severe vine water stress and consequently, negative effects on growth, yield, and berry quality (Lopes et al. 2011; Williams and Matthews 1990).

In the literature, there are several studies showing that cover crop interfere with grapevine water use by decreasing water resources and thus increasing grapevine water stress (mainly early during the spring) (Gulick et al. 1994; Monteiro and Lopes 2007; Morlat 1987; Pou et al. 2011). Whereas, in other studies, it has been shown that cover-cropped vineyards do not always exhibit higher water stress compared to those with bare soil (Celette et al. 2005; Ripoche et al. 2011). Nevertheless, what it is commonly shown is that cover crop clearly interacts with the vines by improving soil properties, including spatial and temporal modifications of the water within the soil profile (Celette et al. 2008). Furthermore, it has been shown that cover crop decreases vine vegetative vigor, as well as showing some increases in vine deeper root fraction, triggered by the competition with cover crop roots (Lopes et al. 2011; Wheeler et al. 2005). In a particular study, Pou et al. (2011) considered not just what happens at soil level, but also, at plant level. This was done by studying the effects of particular cover crops in Mediterranean vineyards on grapevine vegetative growth, intrinsic water use efficiency (WUEi, calculated as the ratio between net leaf photosynthesis $\left(A_{N}\right)$ and stomatal conductance $\left(g_{s}\right)$ ), yield, and grape quality. In a 3-year experiment, three treatments were established as follows: (i) perennial grass and legume mixture; (ii) no tillage, i.e., with permanent resident vegetation; and (iii) traditional tillage or plowed soil (Fig. 3). This study concluded that at the early growing stage, even though sward treatments showed similar or higher $g_{\mathrm{s}}$ and $A_{\mathrm{N}}$ as compared to traditional tillage (likely due to reductions in total leaf area), WUEi did not significantly differ among treatments. However, later in the season, the cover cropped grapevines showed more stable (even higher values) of $g_{\mathrm{s}}, A_{\mathrm{N}}$, and WUEi likely due to a lower water consumption because of the lower plant leaf area (Pou et al. 2011).

Table 2 summarizes the possible pros and cons to use cover crops depending on growing conditions. For water-limited areas, current studies involving cover crops in grapevines showed some positive effects by reducing excessive vegetative growth associated with slight increases in deeper roots jointly with some mulching effect and soil characteristic 


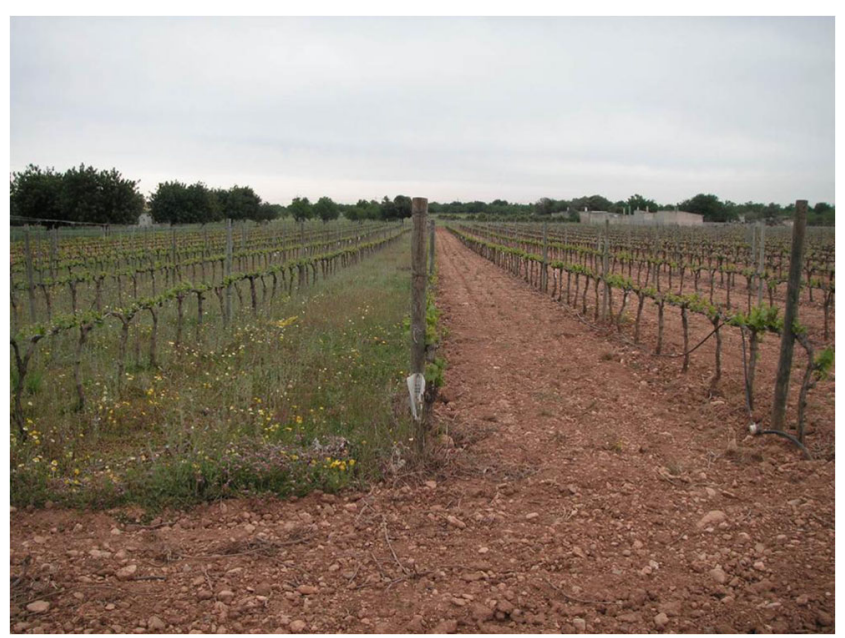

Fig. 3 Contrast soil management in grapevines. Cover crop with natural vegetation vs. traditional tillage ("Hereus de Ribas" vineyards at Consell, Mallorca, Spain)

improvements. The negative effects were clearly identified with the "excessive" plant consumption of available water, which can lead to even harder water stress in dry springs, thus severely reducing crop yield and final plant vigor. These results make a careful management necessary to minimize the risks by choosing appropriate cover crop species that are able to self-reseed and have minimal or complete lack of water consumption after mid spring.

\subsection{Canopy management}

Canopy management is an important agronomic technique being widely used in viticulture to regulate the microenvironment around the clusters, and hence, fruit sanitary conditions, yield, and quality. This effect occurs through the modified light interception in the fruit zone regulated by the training system and hence, orientation, shoot positioning, and leaf area are exposed. The effect of plant architecture on canopy radiation distribution and plant production has been largely studied (Carbonneau 1980; Prieto 2011). However, only few studies have focused on the effects of the canopy on leaf gas exchange (Escalona et al. 2003; Intrigliolo and Lakso 2011; Smart 1974; Williams and Ayars 2005) and WUEi. Medrano et al. (2012) confirmed that WUEi strongly and positively depends on incoming light interception. This study also showed that shaded leaves within the canopy displayed lowest WUEi. A deeper analysis on the relationship among leaf gas exchange parameters and microclimatic conditions for different canopy positions questioned optimization theory for leaf gas exchange (Buckley et al. 2014). These results not only pointed out the difficulties to estimate the whole plant WUE through WUE parameters at leaf level, but also suggested the possibility to improve the whole plant WUE throughout the canopy management (i.e. selective pruning).

\subsection{Irrigation strategies and WUE}

\subsubsection{Deficit irrigation, partial root irrigation, or partial root drying}

Grapevine has been cultivated under rain-fed conditions for a long time in Mediterranean countries linking higher grape and wine quality with the dryer years. During the last three decades, more frequent episodes of drought stress and their intensity required the incorporation of water by irrigation as a way to overcome such limitation and to secure more regular and predictable yields (Chaves et al. 2007, 2010; Flexas et al. 2010). However, two considerations need to be taken in account when irrigating grapevines: (i) water requirements are usually high in semi-arid areas thus potentially compromising water resources and sustainability of agricultural practices (FAO 2014) and (ii) yield increases are commonly associated to grape quality reductions, since grape quality usually decreases in response to an excess of vigor creating an unbalance between the reproductive and vegetative organs within plants (Bravdo et al. 1985; Dokoozlian and Kliewer 1996; Esteban et al. 2001; Matthews et al. 1990; McCarthy 1997). Such tradeoff between yield increase/ quality decreases is clearly dependent on environmental conditions, cultivar, and agronomic practices thus requiring widespread experiments on the relationships among grapevine water status, yield, and quality with important presence in the technical and scientific literature (Table 3).

Within these experiments, different ways to establish irrigation scheduling regimes and timing were proposed based on yield and quality optimization and the concern about more sustainable use of water resources. These important issues lead to the development of irrigation strategies by which grapevines receive a certain fraction of the water required that allows maintaining them under mild or severe water stress conditions with associated effects on yield reductions, maintenance, or increments in berry quality and improved WUE (Costa et al. 2007; Flexas et al. 2010).

Some irrigation strategies that have been developed and used to reduce the amount of water applied to grapevines are deficit irrigation, which in general, corresponds to the classical irrigation strategy used to maintain some degree of water deficit usually leading to maintaining or increasing grape quality at the cost of some reduction of potential yield but with a substantial reduction of water applied. Specifically, deficit irrigation consists on the application of water at lower amounts to the water evapotranspired by the plants or crop (ETc.). Two variants of this strategy have been developed: regulated deficit irrigation and partial root zone drying.

Regulated deficit irrigation is based on the principle that plant sensitivity to water stress (yield, quality) is not constant during all the phenological stages. Therefore, irrigation at lower amounts from ETc. during specific periods may largely 
Table 3 A compilation of studies about irrigation strategies (deficit irrigation, DI; regulated deficit irrigation, RDI; and partial root drying, PRD) on physiological and agronomic parameters and quality of grape and wine

\begin{tabular}{|c|c|c|c|c|}
\hline & & \multicolumn{3}{|l|}{ Irrigation strategy } \\
\hline & & DI & RDI & PRD \\
\hline \multirow{8}{*}{$\begin{array}{r}\text { Physiological } \\
\text { parameters }\end{array}$} & Soil water content & $7,12,14,17,27$ & $16,20,25,27,28$ & $7,12,13,15,17,21,27,28,30$ \\
\hline & Transpiration & $6,7,14,17,19,24,26,27$ & $16,20,27,28$ & $7,8,9,17,18,26,27,28$ \\
\hline & Net photosynthesis & $5,6,14,17,24,27,32$ & $2,27,28,34$ & $2,5,8,9,13,17,27,28,32$ \\
\hline & Stomatal conductance & $4,5,6,17,23,24,26,27$ & 27,28 & $5,8,9,15,17,21,23,26,27,28,33$ \\
\hline & Abscisic acid content & $18,23,26,27$ & 28 & $18,23,26,27,28,33$ \\
\hline & Water potential & $\begin{array}{l}4,5,6,10,11,12,14,17,18 \\
19,21,23,26,31,32\end{array}$ & $1,2,20,22,27,28,29,35$ & $\begin{array}{l}2,5,9,8,10,11,12,13,17,18,21 \\
\quad 23,26,28,30,32,33\end{array}$ \\
\hline & $\begin{array}{l}\text { Intrinsic water use } \\
\text { efficiency }\left(A_{N} / g_{s}\right)\end{array}$ & $5,6,10,14,17,24,27,32$ & 27,28 & $5,8,9,10,17,27,28,32$ \\
\hline & $\begin{array}{l}\text { Carbon discrimination } \\
\left(\delta^{13} \mathrm{C}\right)\end{array}$ & 5,10 & 28,29 & $5,9,10,28$ \\
\hline \multirow{3}{*}{$\begin{array}{l}\text { Agronomic } \\
\text { parameters }\end{array}$} & Yield & $5,7,11,12,14,17,19,24,31$, & $1,2,16,20,22,25,27,29,34,35$ & $2,3,5,7,8,11,12,15,17,21,30$ \\
\hline & $\begin{array}{l}\text { Growth (roots and } \\
\text { aerial tissues) }\end{array}$ & $5,10,11,12,17,27,32$ & $16,20,22,25,28,29,34,35$ & $\begin{array}{l}5,8,10,11,12,13,15,17,21,27 \\
\quad 28,30,32\end{array}$ \\
\hline & Crop WUE & 7,11 & 16 & $7,8,11,15,30$ \\
\hline \multirow[t]{2}{*}{ Quality of grape } & Must composition & $5,11,12,14,17,19,24,31$ & $1,2,16,20,22,25,27,29,34,35$ & $2,3,5,8,11,12,15,17,21,30$ \\
\hline & Phenolic fraction & $5,11,12,17,19,24,31$ & $1,2,16,27,29,35$ & $2,3,5,8,11,12,17,30$ \\
\hline Wine & Wine attributes & & 22 & 8,21 \\
\hline
\end{tabular}

${ }^{1}$ Acevedo-Opazo et al. 2010; ${ }^{2}$ Bassoi et al. 2005; ${ }^{3}$ Bindon et al. $2008 ;{ }^{4}$ Centeno et al. $2010 ;{ }^{5}$ Chaves et al. 2007; ${ }^{6}$ Cifre et al. $2005 ;{ }^{7}$ Collins et al. 2010; ${ }^{8}$ De la Hera et al. 2007; ${ }^{9}$ De Souza et al. 2003; ${ }^{10}$ De Souza et al. 2005; ${ }^{11}$ Dos Santos et al. 2003; ${ }^{12}$ Dos Santos et al. 2007; ${ }^{13}$ Dry and Loveys 1999 ;

${ }^{14}$ Du et al. 2008; ${ }^{15}$ Du toit et al. 2003; ${ }^{16}$ Edwards and Clingeleffer 2013; ${ }^{17}$ Fernandes de Oliveira et al. 2013; ${ }^{18}$ Fuentes et al. $2014 ;{ }^{19}$ Girona et al. 2006; ${ }^{20}$ Greven et al. 2005; ${ }^{21}$ Intrigliolo and Castel 2009; ${ }^{22}$ Intrigliolo and Castel 2010; ${ }^{23}$ Marsal et al. 2008; ${ }^{24}$ Medrano et al. 2003; ${ }^{25}$ Myburgh 2003; ${ }^{26}$ Rodrigues et al. 2008; ${ }^{27}$ Romero et al. 2010, ${ }^{28}$ Romero et al. $2014 ;{ }^{29}$ Santesteban et al. $2011 ;{ }^{30}$ Santos et al. 2005; ${ }^{31}$ Sofo et al. $2012 ;{ }^{32}$ Souza et al. $2005 ;{ }^{33}$ Stoll et al. 2000; ${ }^{34}$ Tarara et al. 2011; Terry and Kurtural 2011

reduce vigor and improve harvest quality, decreasing also the water amount used (Chalmers et al. 1981; Loveys et al. 2004; McCarthy et al. 2002). The regulated deficit irrigation technique can be applied to accomplish different objectives at different phenological stages, i.e., reducing the vigor of berry cell division/berry size (McCarthy et al. 2002) or to induce an accumulation of anthocyanin (Dry et al. 2001). This irrigation strategy requires maintaining the soil and plant water status in a narrow range by regulating irrigation on the basis of environmental information. An excessive reduction of water application can result in severe losses of yield and quality and an excessive irrigation suppresses the advantages of using this strategy by increasing vigor (Jones 2004).

In contrast, partial root zone drying involves wetting and drying approximately half of the root system of plants in cycles of 8-14 days depending on the soil type. This system requires a double irrigation line controlled by different valves that allows irrigating one half of the root system leaving the other half drying in one cycle and shifting sides for wetting and drying in the next cycle. The wet side provides enough water to the plant to avoid water stress, while the drying half is linked to the reduction of stomatal conductance (Zhang et al. 1987). This strategy is based on the knowledge that roots under water stress produce hormonal signals, mainly abscisic acid, a hormone responsible for the stomatal closure and inhibition of growth.

\subsubsection{Effects on plant physiology}

All the irrigation strategies mentioned above have been assessed in field experiments under a wide scope of environmental conditions (soil and climate) and in contrasting grapevine cultivars, thus providing a wide set of results, which sometimes are contradictory. The latter reflects the large genotype/environmental interactions of the plant-available water on the grape behavior. Therefore, a way to have a general overview of these results is to look on the physiological effects on grapevines. To better understand how these strategies affect plant physiology, some of the most general observations among the watering strategies in physiological parameters are described.

Soil water content is reduced using the different irrigation strategies compared to a full irrigation control treatment. This enables grapevines to have a differential behavior in root growth depending on the strategy used. It has been demonstrated that partial root zone drying vines are able to stimulate 
root growth to deeper layers compared to grapevines under deficit irrigation (Dos Santos et al. 2007; Gu et al. 2004; Kriedemann and Goodwin 2003; Stoll et al. 2000). However, this effect was dependent on the soil type or soil water content where grapevines were grown (Collins et al. 2010). Root growth rates under partial root zone drying conditions can change the proportion of roots in a drying soil having implications for abscisic acid synthesis, water extraction, and also nutrient uptake. Partial root zone drying induces also lower canopy leaf area and consequently lowering water use (Chaves et al. 2007; 2010; Davies et al. 2002; Kang and Zhang 2004; Santos et al. 2003; Stoll et al. 2000). These physiological changes observed in partial root zone drying are not always found in all field experiments (Bravdo 2004; Dry et al. 2000a, b; Gu et al. 2004; Intrigliolo and Castel 2009; Marsal et al. 2008). Thus, these contradictory results demonstrate that partial root zone drying as an irrigation strategy is totally dependent on growing conditions (mainly soil characteristics) and genotypes. On the other hand, $g_{\text {s }}$ play a critical role on the regulation of water loss. Under mild to moderate water stress, $g_{\mathrm{s}}$ reduction is the earliest response (Chaves et al. 2003; Medrano et al. 2003) and has been identified in grapevine as a suitable parameter to detect the degree of water stress (Cifre et al. 2005; Medrano et al. 2003). In general, no differences have been observed in $g_{\mathrm{s}}$ between partial root zone drying and deficit irrigation strategies when the same amount of water was applied to the soil (Sadras 2009). However, the dependency of $g_{\mathrm{s}}$ to vapor pressure deficit can be changed under partial root zone drying or deficit irrigation as demonstrated by Collins et al. (2010), likely due to different $g_{\text {s }}$ regulation by abscisic acid.

As it is well known, abscisic acid is one of the main hormonal regulators described for stomatal conductance (Lovisolo et al. 2010; Pou et al. 2008; Rodrigues et al. 2008; Soar et al. 2004; Speirs et al. 2013). Also, it is the fundamental molecule behind the basis of the partial root zone drying strategy since roots under water stress produce abscisic acid and this signal is transported to leaves via xylem inhibiting stomatal conductance and growth rate. Recently, Romero et al. (2014) showed that abscisic acid production could be a function of plant-available water, i.e., of functional roots related to aquaporins. In this sense, some authors linked certain interconnection between abscisic acid signal transduction and aquaporin function (Tyerman et al. 2002). A possible mechanism for increasing root hydraulic conductance as an abscisic acidinduced increased activity of aquaporins was described by Kaldenhoff et al. (1993, 2008) and Thompson et al. (2007). Moreover, it is possible to speculate that abscisic acid loading by xylem to perivascular tissues acts as a signal to trigger the aquaporin-mediated parenchyma-toxylem radial water flow during embolism refilling. In this putative mechanism, abscisic acid would play an indirect role in modulating hydraulic conductivity even in notliving xylem cells via complementary aquaporinmediated cell pathways.

On the other hand, abscisic acid is believed to play an important role for the regulation of berry ripening, as the endogenous abscisic acid concentrations in the berries increase dramatically at the onset of ripening (Coombe and Hale 1973; Düring et al. 1978). Furthermore, exogenous abscisic acid applications on the berries were reported to improve the berry coloring of both table and wine grapes (Jeong et al. 2004; Koyama et al. 2010; Mori et al. 2005a, 2005b; Peppi et al. 2007; Wheeler et al. 2009).

Photosynthesis in grapevines has been demonstrated to be quite resilient to water stress (Chaves et al. 2007; Flexas et al. 2002; De Souza et al. 2003; Tomás et al. 2013) and dependent on the diffusion pathways of $\mathrm{CO}_{2}$ (Flexas et al. 2008, 2012; Tomás et al. 2013, 2014a). Under mild water stress, as photosynthesis is moderately by stomatal closure or mesophyll conductance, an improved $\mathrm{WUE}_{\mathrm{i}}$ is generally reported. This improvement leads to have more carbon assimilation for the same amount of transpiration. Thus, all deficit irrigation strategies improve $\mathrm{WUE}_{\mathrm{i}}$. However, even for a physiological analysis, when different irrigation strategies are compared in $\mathrm{WUE}_{\mathrm{i}}$ terms, no differences were found between them (Cifre et al. 2005; Chaves et al. 2007; De la Hera et al. 2007). Moreover, WUE $_{i}$ could not be an appropriate proxy for the real plant water use efficiency, since this value does not describe the whole canopy behavior of $g_{\mathrm{s}}$ during the whole day and at the whole plant level. There is the need to use more integrated measurements as stable carbon isotope composition $\left(\delta^{13} \mathrm{C}\right)$ (Chaves et al. 2007; De Souza et al. 2003, 2005; Romero et al. 2014; Santesteban et al. 2011). In general, differences between irrigation strategies have been found when the amount of water applied was different (De Souza et al. 2005; Santesteban et al. 2011). For some experiments, some differences have been found between partial root zone drying and regulated deficit irrigation with the same amount of irrigation (Romero et al. 2014) being $\delta^{13} \mathrm{C}$ as a good proxy of integrated WUEc throughout the season. However, depending on the amount of water applied, these differences are not evident (Romero et al. 2014). Therefore, more work is needed to elucidate the whole plant response to identify the optimal WUE.

\subsubsection{Effects on yield, grape, and wine quality}

Deficit irrigation strategies are relatively new tools for managing grapevine growth, improving fruit quality and WUE, while maintaining or slightly reducing yields. One of these strategies as discussed before is regulated deficit irrigation, which has been explored to control vegetative growth (Edwards and Clingeleffer 2013; Greven et al. 2005; Intrigliolo and Castel 2010; Santesteban et al. 2011; Tarara et al. 2011; 
Terry and Kurtural 2011). This technique improves vigor by reducing water application and yield per unit water supply (Acevedo-Opazo et al. 2010; Edwards and Clingeleffer 2013; Myburgh 2003; Tarara et al. 2011). On the other hand, partial root zone drying has the effect of controlling excessive vegetative growth in grapevines leading to a reduction in canopy density and a better plant balance with decreased input costs (water and nutrients). This effect leads to an increase of grape quality presumably without yield modification (Chaves et al. 2007; De la Hera et al. 2007; dos Santos et al. 2003, 2007; Dry and Loveys 1999; Intrigliolo and Castel 2009; Romero et al. 2010, 2014; Santos et al. 2005; Souza et al. 2005). However, when a big set of existing data is compared, no relationship between total water applied and yield is observed (Fig. 4a). This lack of correspondence can be explained due to yield having been affected not only by watering amount and irrigation management, but also by the environment and vineyard conditions, namely soil characteristics, cultivar, and viticultural practices (Fig. 4a). When comparing WUEc to yield or water used, the response is clearly different (Fig. 4b, c). Figure $4 \mathrm{~b}$ shows the significant correspondence between WUEc and yield. However, a wider dispersion of data is observed when WUEc is plotted vs. water used (Fig. 4c). Nevertheless, as Fig. 4c shows, the highest values of WUEc for any water used data shows a clear line, which can be understood as that maximum WUEc and linearly drops when the amount of water used increases. In water-limited areas, the application of deficit irrigation practices can also provide growers with a tool to manipulate fruit composition to enhance and modulate the season-to-season variation in red wine quality attributes (De la Hera et al. 2007; Intrigliolo and Castel $2009,2010)$ and to manipulate wine sensory characteristics (Matthews et al. 1990). Deficit irrigation, as compared to full irrigation, may also improve berry quality due to an increment in the contents of anthocyanins and total phenols (Chaves et al. 2007; Girona et al. 2006; Medrano et al. 2003; Santos et al. 2005; Sofo et al. 2012) even though this response is also cultivar dependent. The effects of regulated deficit irrigation on fruit growth and quality are neutral or positive, while keeping vineyard vigor in balance with potential production (Girona et al. 2006; Greven et al. 2005; Intrigliolo and Castel 2009). Understanding the effects of timing and amount of irrigation on berry composition is a key to achieve the desired berry quality. Moreover, partial root zone drying can also produce a significant modification on grape composition and wine spectral properties compared with that of a control (De la Hera et al. 2007; Intrigliolo and Castel 2009).

In summary, deficit irrigation strategies can help to reduce plant water use by adjusting total leaf area, and at the same time, to maintain or improve fruit quality with almost no changes in yield. However, the effects of deficit irrigation strategies in WUE are not conclusive and the results are in some cases, contradictories. Many factors as genotypes, environment, soil management (fertilization, tillage system, cover crop, and mulching) and crop management (pruning, trellis system, partial defoliation), can influence in plant behavior to deficit irrigation strategies, mainly in relation to water use efficiency.

\section{Genetic variability of water use efficiency}

\subsection{Cultivar influence in WUE}

Genetic improvement of crops has been an important basis of the general increase of productivity in the last decades on the basis of a different selection criteria and existing genetic variability. In the case of grapevines, the result of this large selection is a great variety of commercial cultivars, which can be considered as one of the biggest among actual crops.

Thousands of grapevine cultivars have been described around the world (OIV 2009; This et al. 2006) showing an impressive genetic variability and plasticity of the grapevine genome. This variability offers an invaluable genetic resource to cope with crop adaptation to the different environmental conditions and potentially to climate change. There is no reference about the use of WUE as selection criteria, but there are cultivars reputed as more adapted to drought-prone conditions, which presumably should also present high WUE. Nowadays, the importance of this character and the necessity of a more sustainable crop forces the necessity to evaluate the variability of WUE among existing cultivars.

The existence of genetic variability in WUEi was demonstrated earlier by Bota et al. (2001) and Gaudillère et al. (2002), which measured WUEi and the surrogate character $\delta^{13} \mathrm{C}$, respectively. However, as mentioned before, there are difficulties to estimate the whole plant WUE through WUEi. A recent study performed in different cultivars of grapevine confirmed previous results by showing that there is no consistent correlation between parameters measured at leaf and whole canopy levels (Tomás et al. 2012). The possible causes of this lack of correlation, explained in detail in different reviews (Flexas et al. 2010; Medrano et al. 2012; Schultz and Stoll 2010; Tarara et al. 2011; Tomás et al. 2014a) are associated to the complexity of the canopy structure, and two physiological mechanisms, leaf night transpiration and plant respiration.

In consequence, it seems necessary to amplify our knowledge about the variation of those components for plant WUE in order to assess properly leaf WUE variability within the canopy.

Many studies performed at the leaf level have shown a wide range of intra-specific variability of WUEi among cultivars, (Gómez-Alonso and García-Romero 2010; Bota et al. 2001; Costa et al. 2012; Gaudillère et al. 2002; Gómez- 
Fig. 4 Relation between total water applied (rainfall from April to September + irrigation) and yield and crop water use efficiency. Data are collected from Acevedo-Opazo et al. 2010; Bassinger and Hellman 2007; Bindon et al. 2008; Chaves et al. 2007; De la Hera et al. 2007; Edwards and Clingeleffer 2013; Girona et al. 2006; Greven et al. 2005; Intrigliolo and Castel 2010; dos Santos et al. 2007; Romero et al. 2010; Santos et al. 2005; Tarara et al. 2011. Circles full irrigation, squares partial root zone drying, triangles deficit irrigation, diamonds regulated deficit irrigation. Red line represents the theoretical maximum water use efficiency (WUE) for each soil total water availability level. Black line in $\mathbf{b}$ represents linear regression $\left(r^{2}=\right.$ 0.76)

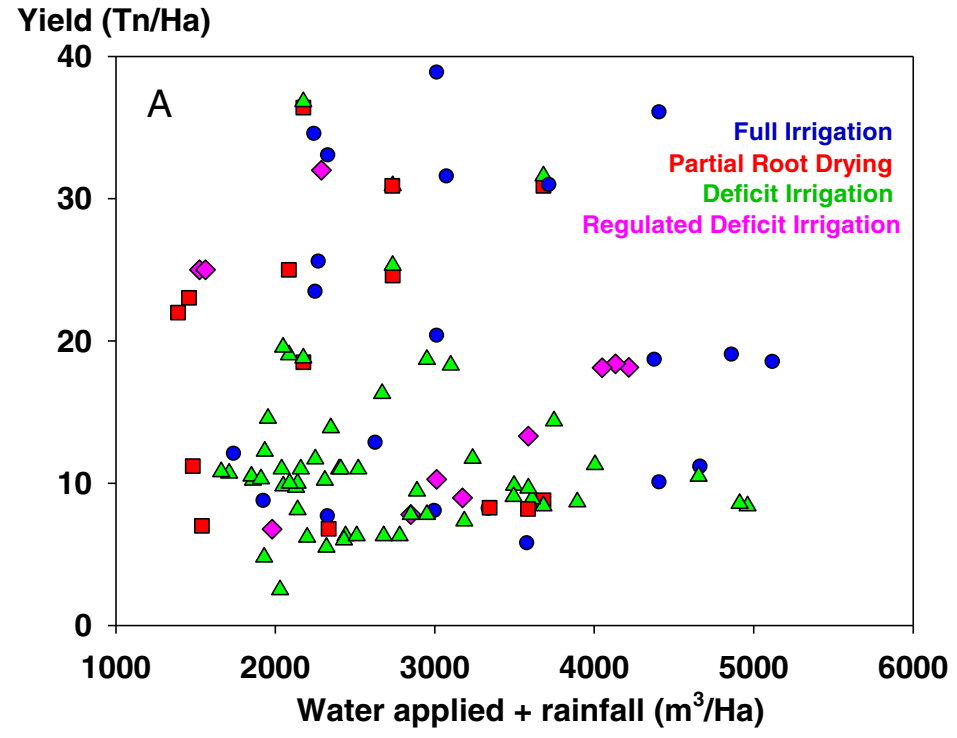

WUE (Kg fresh grape $/ \mathrm{m}^{3}$ water applied)

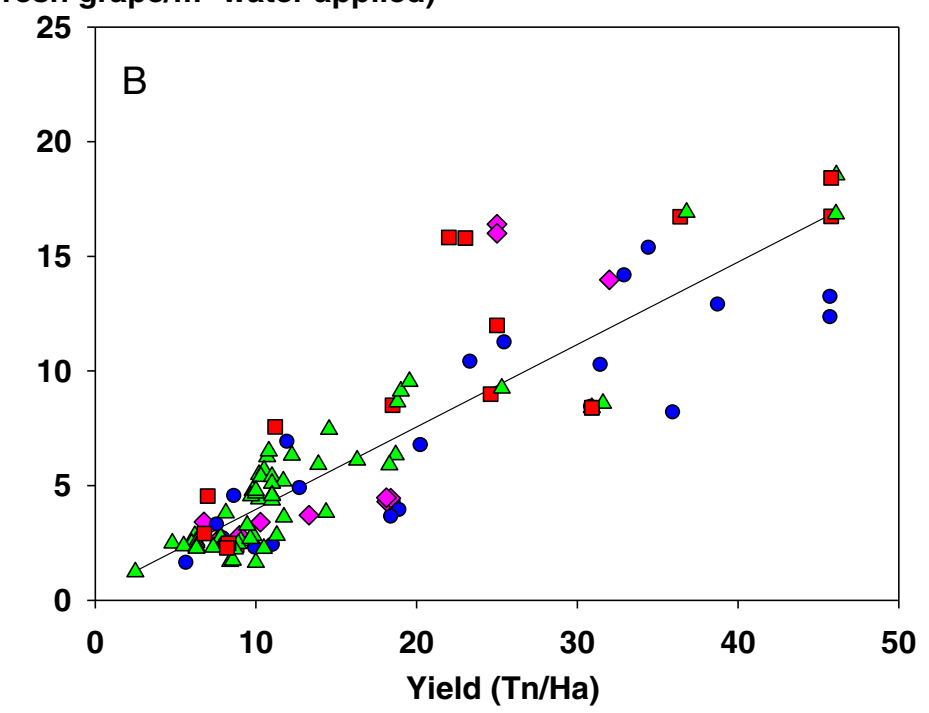

WUE (Kg fresh grape $/ \mathrm{m}^{3}$ water applied)

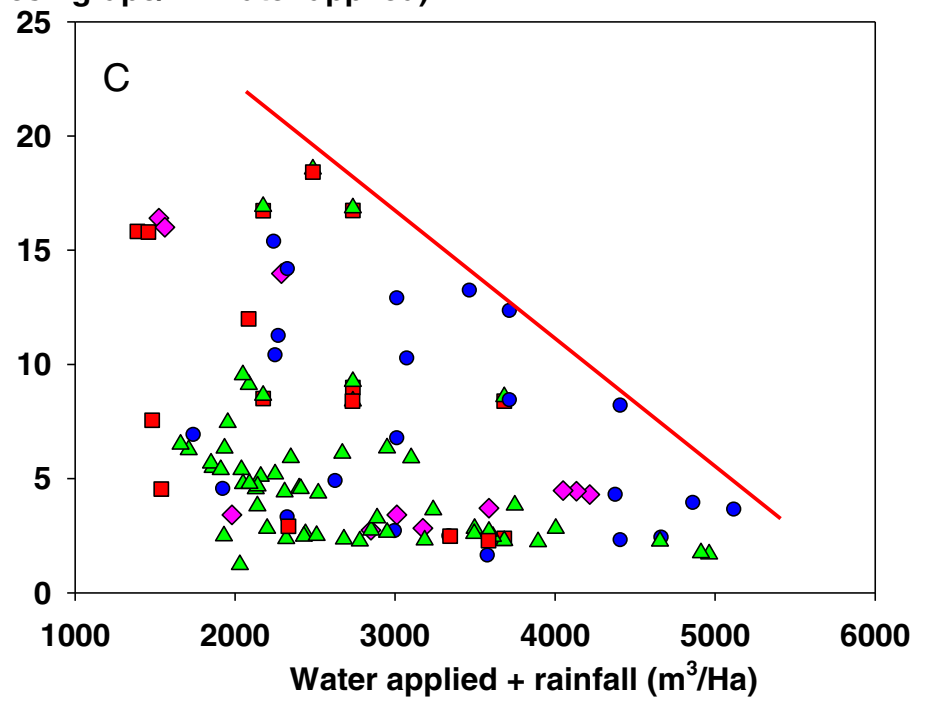


Koundouras et al. 2008; Pou et al. 2008; Prieto et al. 2010; Rogiers et al. 2011; Schultz 2003; Souza et al. 2005; Tomás et al. 2012, 2014b; Zsófi et al. 2009). This variability is mostly associated to different $g_{\mathrm{s}}$ responses, as shown by Tomás et al. (2014a), which assessed 74 different cultivars under irrigation and drought conditions. In Table 4, a large range of WUEi is shown among the different cultivars under irrigation, ranging from $12 \mu \mathrm{mol} \mathrm{CO}{ }_{2} \mathrm{~mol}^{-1} \mathrm{H}_{2} \mathrm{O}$ in Syrah to $117.6 \mu \mathrm{mol} \mathrm{CO}$ $\mathrm{mol}^{-1} \mathrm{H}_{2} \mathrm{O}$ in Monastrell. Under drought conditions, the WUEi values are higher in all cultivars. Minimum values are similar to irrigated conditions with the cultivar Tas-A-Ganesh presenting the lowest values $\left(16 \mu \mathrm{mol} \mathrm{CO} \mathrm{Col}^{-1} \mathrm{H}_{2} \mathrm{O}\right)$. However, WUEi under drought was the maximum for Syrah and Rosaki (200 $\mu \mathrm{mol} \mathrm{CO} \mathrm{mol}^{-1} \mathrm{H}_{2} \mathrm{O}$ in both cultivars). Focusing only in widely grown wine cultivars, there is also a considerable range of variation under irrigation (around $70 \%$ ), which increased under drought to $84 \%$. It is worthy to point out that within a single cultivar, a large variability of WUEi was also observed depending on the environmental conditions of each experiment (Table 4). In fact, it has been shown by different studies that the same cultivar can behave different significantly with water economy parameters being qualified as iso- or anisohydric cultivar along the growing season (Poni et al. 1993) or between experimental years (Pou et al. 2012) or by changing the irrigation strategy (Collins et al. 2010). Therefore, the classification of cultivars in two different categories, iso- and anisohydric behaviors, based on the different $g_{\mathrm{s}}$ behaviors related to water potential, is not always helpful, as reported in different comparisons (Chaves et al. 2010; Pou et al. 2012; Tomás et al. 2014a).

Besides genetic variability of WUEi in the short term, substantial differences in long-term measurements $\left(\delta^{13} \mathrm{C}\right)$ have also been reported for grapevines. More than $3 \%$ variations under irrigation and drought conditions in $\delta^{13} \mathrm{C}$ has been reported; however, less cultivars have been studied using this parameter (Costa et al. 2012; Flexas et al. 2010; Gaudillère et al. 2002; Tomás et al. 2014a). Different types of whole plant measurements are used to estimate plant WUE depending on the specific study. These measurements are based on the vegetative growth rate and water consumption (g dry matter $/ \mathrm{kg} \mathrm{H}_{2} \mathrm{O}$ ) or whole canopy gas exchange measurements ( $\mathrm{mmol} \mathrm{CO} \mathrm{C}_{2} / \mathrm{mol} \mathrm{H}_{2} \mathrm{O}$ ), performed in potted plants or in the field, respectively. Gibberd et al. (2001) and Tomás et al. (2012) measured 19 and 9 different potted cultivars, respectively, showing important differences among cultivars as was shown by Poni et al. 2009 and Tomás et al. (2014b) demonstrating the existence of genetic variability in the whole plant WUE.

The large variability of WUE identified among cultivars and within a single variety at the leaf and whole plant level offers an opportunity to select the most appropriate cultivar depending on the environmental crop conditions.
3.2 Rootstock influence in WUE and rootstock-scion interactions

Although most studies are restricted to cultivated grapevine, it is important to deem the variability observed in plants included in the genus Vitis, which can provide a potential genetic resource to improve WUE or at least the green water consumption by rootstocks. In Table 4, it is shown that 19 Vitis species with significant differences in WUEi among them, from 11.2 to $154 \mu \mathrm{mol} \mathrm{CO} \mathrm{mol}^{-1} \mathrm{H}_{2} \mathrm{O}$ under irrigation; and ranging between 13 and $132.1 \mu \mathrm{mol} \mathrm{CO} \mathrm{mol}^{-1} \mathrm{H}_{2} \mathrm{O}$ under drought conditions. Vitis berlandieri and Vitis labruscana presented the minimum and maximum values, respectively. It is important to take into account that the genetic variability of WUEi observed in different studies, most of them performed with grafted plants, could partly be explained by a rootstock effect (Koundouras et al. 2008; Serra et al. 2014).

Interest in rootstock studies was initially triggered by the need to introduce resistance to the phylloxera plague and the fungal pathogens that were devastating European viticulture (Bouquet 2011). Later, tolerance to abiotic stresses of rootstocks became a priority owing to the impact on plant production (Webb et al. 2011). Tolerance to cold, drought, salinity, calcareous soils, low $\mathrm{pH}$ soils, and aluminum toxicity are some of the tolerance traits that have been demonstrated in rootstocks (Bavaresco et al. 1995; Cançado et al. 2009; Himelrick 1991; Padgett-Johnson et al. 2003). The studies about rootstocks effect on plant adaptation to water stress conditions have recently increased due to the rootstock capacity to extract water from the soil and to control and adjust the water supply to shoot transpiration demand (Alsina et al. 2011; Marguerit et al. 2012; Tramontini et al. 2013). However, studies about variability of WUE in rootstocks are scarce. Satisha et al. (2006) showed significant differences in WUE is studied in ten different rootstocks, ranging from 1.21 to $1.57 \mu \mathrm{mol} \mathrm{CO} \mathrm{mol}^{-1} \mathrm{H}_{2} \mathrm{O}$, while Jacobs (2014) did not find differences WUEi between four different rootstocks.

On the other hand, the interactions of rootstock scion have shown different WUE results in comparison with ungrafted plants. Differences in the horizontal and vertical distribution of rooting depth, root hydraulic capacity through the anatomical characteristics of the xylem vessels (Alsina et al. 2011; Pongrácz and Beukman 1970), and root aquaporin gene expression (Fouquet 2005; Gambetta et al. 2013; Lovisolo et al. 2008; Vandeleur et al. 2009), are the possible causes associated to the variability of scion's gas exchange parameters observed on grafted plants (Serra et al. 2014). However, the scarce and contradictory results show the need to increase studies about genetic variability of WUE in rootstocks-scion interaction that could play a fundamental role in the plant adaptation to future climate change. 
Table 4 List of references on genetic variability of the leaf water use efficiency estimated as WUEi $\left(\mathrm{A}_{\mathrm{N}} / \mathrm{g}_{\mathrm{s}}\right)$ characterized by the water potential $(\Psi)$ range corresponding to irrigation and water stress treatments. In the case of cultivars studied by more than one report, the range of WUEi is showed

\begin{tabular}{|c|c|c|c|c|c|}
\hline \multirow[t]{2}{*}{ Reference } & \multirow[t]{2}{*}{ Cultivar } & \multicolumn{2}{|c|}{ Irrigation treatment } & \multicolumn{2}{|c|}{ Water stress treatment } \\
\hline & & $\begin{array}{l}\Psi \\
(-\mathrm{MPa})\end{array}$ & $\begin{array}{l}\mathrm{A}_{\mathrm{N}} / \mathrm{g}_{\mathrm{s}} \\
\left(\mu \mathrm{mol} \mathrm{CO} \mathrm{CO}_{2} \# \mathrm{~mol}^{-1} \mathrm{H}_{2} \mathrm{O}\right)\end{array}$ & $\begin{array}{l}\Psi \\
(-\mathrm{MPa})\end{array}$ & $\begin{array}{l}\mathrm{A}_{\mathrm{N}} / \mathrm{g}_{\mathrm{s}} \\
\left(\mu \mathrm{mol} \mathrm{CO} \mathrm{CO}_{2}\right. \\
\left.\mathrm{mol}^{-1} \mathrm{H}_{2} \mathrm{O}\right)\end{array}$ \\
\hline Gómez-del-Campo et al. 2002, 2004, 2007 & Airen & $0.11-0.17$ & $28.1-68.2$ & $0.25-0.46$ & $30.6-48.8$ \\
\hline Bota et al. 2001 & Aleluya & 0.057 & 47.3 & 0.41 & 39 \\
\hline Costa et al. 2012; Maroco et al. 2002 & Aragonez & $0.13-0.8$ & $35-60$ & $0.25-1$ & $55.5-200$ \\
\hline Bota et al. 2001 & Argamussa & 0.035 & 44.7 & 0.45 & 111 \\
\hline Patakas et al. 2003a & Asirtiko & 0.4 & 62.2 & 1 & 52.9 \\
\hline Ghaderi et al. 2011 & Askari & 0.2 & 36.1 & $0.6-1$ & $55.4-95.1$ \\
\hline Patakas et al. 2003a & Athiri & 0.4 & 62.2 & 1 & 53 \\
\hline Bota et al. 2001 & Batista & 0.092 & 51.33 & 0.2 & 58.6 \\
\hline Ghaderi et al. 2011 & Bidane-Sefid & 0.2 & 19.7 & $0.6-1$ & $50.8-77.9$ \\
\hline Bota et al. 2001 & Boal & 0.13 & 40.7 & 0.46 & 57.1 \\
\hline $\begin{array}{l}\text { Dobrowsky et al. 2005; Bota et al. 2001; } \\
\text { Rogiers et al. 2009; Santesteban et al. } \\
\text { 2009; Tomás et al. } 2012\end{array}$ & $\begin{array}{l}\text { Cabernet } \\
\text { Sauvignon }\end{array}$ & $0.037-0.31$ & $42-84.2$ & $0.21-1.73$ & $89.8-145.8$ \\
\hline Bota et al. 2001; Tomás et al. 2012, 2014a, b & Callet & 0.06 & $37.8-73.2$ & 0.2 & $38.8-114.5$ \\
\hline Bota et al. 2001 & Calop Blanc & 0.08 & 68.8 & 0.44 & 72.6 \\
\hline $\begin{array}{l}\text { Winkel and Rambal 1993; Padgett-Johnson } \\
\text { et al. } 2000\end{array}$ & Carignane & $0.1-0.2$ & 36 & 0.4 & 42.8 \\
\hline $\begin{array}{l}\text { Chaves et al. 2007; Rodrigues et al. 2008; } \\
\text { Souza et al. } 2005\end{array}$ & Castelao & $0.25-0.26$ & $60-81.8$ & $0.78-0.8$ & $50-80$ \\
\hline $\begin{array}{l}\text { Bota et al. 2001; Gómez-del-Campo et al. } \\
\text { 2002, 2004, 2007; Flexas et al. 1999; } \\
\text { Pou et al. 2012; Rogiers et al. } 2009\end{array}$ & Chardonnay & $0.063-0.34$ & $26.4-76$ & $0.28-0.4$ & $30.8-161.3$ \\
\hline Zufferey et al. 2000 & Chasselas & 0.075 & 71.4 & 0.63 & 85.2 \\
\hline Bota et al. 2001; Tomás et al. 2012, 2014a, b. & Escursac & 0.025 & $62.2-71.7$ & 0.21 & $60.2-113.2$ \\
\hline Bota et al. 2001 & Esperó de gall & 0.063 & 48.7 & 0.39 & 44.2 \\
\hline Satisha et al. 2006; Rogiers et al. 2009 & Flame seedless & 0.32 & $17.5-52.5$ & 0.39 & $22.2-44.2$ \\
\hline Bota et al. 2001 & Fogoneu & 0.047 & 56.3 & 0.24 & 65 \\
\hline Bota et al. 2001 & Gorgollassa & 0.053 & 58 & 0.27 & 65.15 \\
\hline $\begin{array}{l}\text { Gómez-del-Campo et al. 2002, 2004; Pou } \\
\text { et al. 2012; Santesteban et al. 2009; } \\
\text { Schultz 2003; } \\
\text { Tomás et al. 2012, 2014a, b }\end{array}$ & Grenache & $0.1-0.34$ & $57.4-83.3$ & $0.46-0.85$ & $50.2-151$ \\
\hline Bota et al. 2001 & Giró & 0.06 & 56.1 & 0.32 & 64 \\
\hline Flexas et al. 1999 & Gordot & & 53.1 & & 21.4 \\
\hline Bota et al. 2001 & Grumiere & 0.06 & 41.6 & 0.37 & 63.3 \\
\hline Patakas et al. 2003b & $\begin{array}{l}\text { Isabella } \\
\text { (V. labrusca) }\end{array}$ & 0.05 & 93.3 & & \\
\hline Zsófi et al. 2009 & Kekfrankos & 0.15 & 47.8 & 0.32 & 55.3 \\
\hline Ghaderi et al. 2011 & Koshnave & 0.2 & 26.4 & $0.6-1$ & $52.3-98.6$ \\
\hline Poni et al. 2009 & Lambrusco & & 63 & & 103 \\
\hline Patakas et al. 2005 & Melagouzia & 0.15 & 90 & $0.4-0.42$ & $80-85.7$ \\
\hline Bota et al. 2001; Tomás et al. 2012, 2014a, b & Malvasia & 0.053 & $48.7-64.8$ & 0.43 & $71-121$ \\
\hline Bota et al. 2001 & Mancín & 0.082 & 52.2 & 0.32 & 52.7 \\
\hline $\begin{array}{l}\text { Bota et al. 2001; Escalona et al. 1999, 2003; } \\
\text { Tomás et al. 2012, 2014a, b }\end{array}$ & Manto Negro & $0.04-0.13$ & $41.6-68.2$ & $0.18-0.45$ & $66.7-97$ \\
\hline $\begin{array}{l}\text { Rogiers et al. 2009; Sivilotti et al. 2005; } \\
\text { Santesteban et al. } 2009\end{array}$ & Merlot & $0.15-0.31$ & $45.7-71$ & $0.15-1.25$ & $51.4-120$ \\
\hline Bota et al. 2001; De la Hera et al. 2007 & Mollar & 0.08 & 41.3 & 0.34 & 59.3 \\
\hline
\end{tabular}


Table 4 (continued)

\begin{tabular}{|c|c|c|c|c|c|}
\hline \multirow[t]{2}{*}{ Reference } & \multirow[t]{2}{*}{ Cultivar } & \multicolumn{2}{|c|}{ Irrigation treatment } & \multicolumn{2}{|c|}{ Water stress treatment } \\
\hline & & $\begin{array}{l}\Psi \\
(-\mathrm{MPa})\end{array}$ & $\begin{array}{l}\mathrm{A}_{\mathrm{N}} / \mathrm{g}_{\mathrm{s}} \\
\left(\mu \mathrm{mol} \mathrm{CO} \mathrm{CO}_{2} \# \mathrm{~mol}^{-1} \mathrm{H}_{2} \mathrm{O}\right)\end{array}$ & $\begin{array}{l}\Psi \\
(-\mathrm{MPa})\end{array}$ & $\begin{array}{l}\mathrm{A}_{\mathrm{N}} / \mathrm{g}_{\mathrm{s}} \\
\left(\mu \mathrm{mol} \mathrm{CO} \mathrm{CO}_{2}\right. \\
\left.\mathrm{mol}^{-1} \mathrm{H}_{2} \mathrm{O}\right)\end{array}$ \\
\hline Romero et al. 2012 & Monastrell & $0.065-0.98$ & $44.3-117.6$ & $0.26-0.9$ & $42.4-112.4$ \\
\hline $\begin{array}{l}\text { Chaves et al. 2007; Rodrigues et al. 2008; } \\
\text { Souza et al. } 2005\end{array}$ & Moscatel & 0.2 & $50-60.9$ & $0.6-0.64$ & $63.6-77$ \\
\hline $\begin{array}{l}\text { Poni et al. 1993; Rogiers et al. 2009; Tomás } \\
\text { et al. 2012; 2014a, b }\end{array}$ & Pinot Noir & $0.16-0.32$ & $37.8-66.7$ & $0.18-0.62$ & 83.2 \\
\hline Bota et al. 2001 & Prensal Blanc & 0.063 & 38.5 & 0.23 & 38 \\
\hline Bota et al. 2001 & Quigat & 0.06 & 55.7 & 0.25 & 52.1 \\
\hline Patakas et al. 2003b & Ribier & 0.05 & 71.4 & & \\
\hline $\begin{array}{l}\text { Downton et al. 1987; Flexas et al. 1999; } \\
\text { Rogiers et al. } 2009\end{array}$ & Riesling & $0.32-0.9$ & $27.1-43.4$ & 0.83 & $33.3-91.3$ \\
\hline Quick et al. 1992; Rodrigues et al. 1993 & Rosaki & 0.1 & $100-110$ & $0.06-1.1$ & $60-200$ \\
\hline Bota et al. 2001 & Sabater & 0.043 & 49.4 & 0.18 & 71.2 \\
\hline Naor and Wample 1994; Rogiers et al. 2009 & Sauvignon Blanc & 0.28 & $26.9-51.7$ & & \\
\hline Rogiers et al. 2009, 2011 & Semillon & 0.45 & $35.7-54.3$ & & 71.4 \\
\hline Satisha et al. 2006 & Sharad seedless & & 17.8 & & 18.1 \\
\hline $\begin{array}{l}\text { Patakas et al. 2003a; Pou et al. 2012; } \\
\text { Rogiers et al. 2009; Schultz 2003; } \\
\text { Schultz and Stoll } 2010\end{array}$ & Syrah & $0.1-0.34$ & $46.5-70$ & $0.19-1.15$ & $50.5-200$ \\
\hline Rogiers et al. 2009 & Sultana & 0.28 & 40.5 & & \\
\hline Satisha et al. 2006 & Tas-A-Ganesh & & 18.2 & & 16 \\
\hline $\begin{array}{l}\text { Escalona et al. 1999, 2003; Gómez-del- } \\
\text { Campo et al. 2002, 2004; Santesteban } \\
\text { et al. 2009; } \\
\text { Tomás et al. 2012, 2014a, b }\end{array}$ & Tempranillo & $0.03-032$ & $44-84$ & $0.31-0.49$ & $52.1-120$ \\
\hline Satisha et al. 2006 & Thomson seedless & & 18.5 & & 20 \\
\hline Moutinho-Pereira et al. 2004 & Touriga Nacional & 0.25 & 26.6 & $0.1-0.8$ & $80-135.6$ \\
\hline Correia et al. 1990, 1995; Costa et al. 2012 & Tricadeira Preta & $0.2-0.42$ & $25-78$ & $0.1-0.68$ & $50-190.5$ \\
\hline
\end{tabular}

\section{Concluding remarks}

The sustainability of grapevine production largely needs a serious consideration regarding the environmental impact of the large amount of irrigation volume and the foreseeing increases of irrigation necessities according to future climate change scenarios. In this way, this work summarized the efforts to improve WUEc considering two main approaches: agronomic and genetic.

Even though there is an important volume of work that aims at reducing irrigation water consumption by using different irrigation methodologies, the meta-analysis of this literature clearly shows that increasing WUEc can only be achieved by reducing the total amount of water used, which generally means a certain reduction of yield. Fortunately, increasing fruit quality characteristics can compensate yield losses. However, the large variation in WUEc below the roof of the water consumption vs. WUEc shows that results are highly dependent on the environmental and genetic components reducing the determinism of this relationship and offering at time a wide opportunity to improve the WUEc according to the particular cropping conditions.

The capacity to improve the proportion of the green water use relies on the introduction of mulching and cover crops practices, which needs further work mainly to achieve a comparative water-saving quantification under different environmental conditions. On the other hand, the genetic improvement strategy is just starting to be explored in recent researches, showing important variability both for the rootstock's capacity to extract water from the soil as for the scions to a more economic use of water. In both cases, there is a paucity of information on the heritability and genetic basis of the observed differences in WUE, which should be solved before starting a wide selection program. A main limitation pending on this subject is also the representativeness or links among the surrogate characteristics of the WUEc, and the WUEi or the $\delta^{13} \mathrm{C}$. 
As a general conclusion, the present work showed a clear necessity of wider efforts to progress in the field of WUE improvement at the needed timing to secure the sustainability of this important crop in the near future.

\section{References}

Acevedo-Opazo C, Ortega-Farias S, Fuentes S (2010) Effects of grapevine (Vitis vinifera L.) water status on water consumption, vegetative growth and grape quality: an irrigation scheduling application to achieve regulated deficit irrigation. Agric Water Manag 97:956964. doi:10.1016/j.agwat.2010.01.025

Agnew RH, Mundy DC, Spiers TM (2002) Mulch for sustainable production. Booklet produced for Marlborough District Council, Christchurch

Agnew RH, Mundy DC, Spiers TM, Greven MM (2005) Waste stream utilization for sustainable viticulture. Water Sci Technol 51:1-8

Alsina MM, De Herralde F, Aranda X, Save R, Biel C (2007) Water relations and vulnerability to embolism are not related: experiments with eight grapevine cultivars. Vitis 46:1-6

Alsina MM, Smart DR, Bauerle T, De Herralde F, Biel C, Stockert C, Save R (2011) Seasonal changes of whole root system conductance by a drought-tolerant grape root system. J Exp Bot 62:99-109. doi: $10.1093 /$ jxb/erq247

Bassinger AR, Hellman EW (2007) Evaluation of regulated deficit irrigation on grape in Texas and implications for acclimation and cold hardiness. Int J Fru Sci 6:3-22. doi:10.1300/J492v06n02 02

Bassoi LH, Dantas BF, Lima Filho JMP, Lima MAC, Leao PCS, Silva DJ, Ramos MM (2005) Preliminary results of a long-term experiment about RDI and PRD irrigation strategies in winegrapes in São Francisco Valley, Brazil. In: International Workshop on Advances in Grapevine and Wine Research 754, pp 275-282

Bavaresco L, Fregoni M, Perino A (1995) Physiological aspects of limeinduced chlorosis in some Vitis species. II. Genotype response to stress conditions. Vitis 34:233-234

Bindon K, Dry P, Loveys B (2008) Influence of partial rootzone drying on the composition and accumulation of anthocyanins in grape berries (Vitis vinifera cv. Cabernet Sauvignon). Aust J Grape Wine Res 14: 91-103. doi:10.1111/j.1755-0238.2008.00009.x

Bota J, Flexas J, Medrano H (2001) Genetic variability of photosynthesis and water use in Balearic grapevine cultivars. Ann Appl Biol 138: 353-365

Bouquet A (2011) Grapevines and viticulture. In: Adam-Blondon AF, Martinez-Zapater JM, Kole C (eds) Genetics, genomics, and breeding of grapes. Science Publishers, Jersey, pp 1-29

Bravdo BA (2004) Physiological mechanisms involved in the production of non-hydraulic root signals by partial rootzone drying - a review. In: VII International Symposium on Grapevine Physiology and Biotechnology 689, pp 267-276

Bravdo BA, Hepner Y, Loinger C, Cohen S, Tabacman H (1985) Effect of irrigation and crop level on growth, yield and wine quality of cabernet sauvignon. Am J Enol Viticult 36:132-139

Buckerfield J, Webster K (2001) Responses to mulch continue: results from five years of field trials. Aust NZ Grapegrow Winemak 453:71-78

Buckley TN, Martorell S, Diaz-Espejo A, Tomàs M, Medrano H (2014) Is stomatal conductance optimized over both time and space in plant crowns? A field test in grapevine (Vitis vinifera). Plant Cell Environ. doi: $10.1111 /$ pce. 12343

Cançado GMA, Ribeiro AP, Pineros MA, Miyata LY, Alvarenga AA, Villa F, Pasqual M, Purgatto E (2009) Evaluation of aluminium tolerance in grapevine rootstocks. Vitis 48:167-173
Carbonneau A (1980) Recherche sur les systèmes de conduite de la vigne: essai de maîtrise du microclimat et de la plante entière pour produire économiquement du raisin de qualité. Dissertation, Université du Bordeaux II

Celette F, Wery J, Chantelot E, Celette J, Gary C (2005) Belowground interactions in a vine (Vitis vinifera L.)-tall fescue (Festuca arundinacea Shreb.) intercropping system: water relations and growth. Plant Soil 276:205-217. doi:10.1007/s11104-005-4415-5

Celette F, Gaudin R, Gary C (2008) Spatial and temporal changes to the water regime of a Mediterranean vineyard due to the adoption of cover cropping. Eur J Agron 29:153-162. doi:10.1016/j.eja.2008. 04.007

Centeno A, Pilar Baeza P, Lissarrague JR (2010) Relationship between soil and plant water status in wine grapes under various water deficit regimes. Hortictechnol 20:585-593

Chalmers DJ, Mitchell PD, Van Heek L (1981) Control of peach tree growth and productivity by regulated water supply, tree density and summer pruning. J Am Soc Hortic Sci 106:307-312

Chaves MM, Maroco JP, Pereira JS (2003) Understanding plant responses to drought. From genes to the whole plant. Funct Plant Biol 30:239-264. doi:10.1071/FP02076

Chaves MM, Santos TP, Souza CR, Ortuño MF, Rodrigues ML, Lopes CM, Maroco JP, Pereira JS (2007) Deficit irrigation in grapevine improves water-use efficiency while controlling vigour and production quality. Ann Appl Biol 150:237-252. doi:10.1111/j.1744-7348. 2006.00123 x

Chaves MM, Zarrouk O, Francisco R, Costa JM, Santos T, Regalado AP, Rodrigues ML, Lopes CM (2010) Grapevine under deficit irrigation: hints from physiological and molecular data. Ann Bot 105: 661-676. doi:10.1093/aob/mcq030

Cifre J, Bota J, Escalona JM, Medrano H, Flexas J (2005) Physiological tools for irrigation scheduling in grapevines: an open gate to improve water use efficiency? Agric Ecosyst Environ 106:159-170

Clark A (2007) Managing cover crops profitably, 3rd edn. Sustainable Agriculture Network, Beltsville

Collins MJ, Fuentes S, Edward Barlow E (2010) Partial rootzone drying and deficit irrigation increase stomatal sensitivity to vapour pressure deficit in anisohydric grapevines. Funct Plant Biol 37:128-138. doi: 10.1071/FP09175

Coombe BG, Hale CR (1973) The hormone content of ripening grape berries and the effects of growth substance treatments. Plant Physiol 51:629-634

Correia MJ, Chaves MM, Pereira JS (1990) Afternoon depression in photosynthesis in grapevine leaves - evidence for a high light stress effect. J Exp Bot 41:417-426. doi:10.1093/jxb/41.4.417

Correia MJ, Pereira JS, Chaves MM, Rodrigues ML, Pacheco CA (1995) ABA xylem concentrations determine maximum daily leaf conductance of field-grown Vitis vinifera L. plants. Plant Cell Environ 18: 511-521. doi:10.1111/j.1365-3040.1995.tb00551.x

Costa JM, Ortuño MF, Chaves MM (2007) Deficit irrigation as strategy to save water: physiology and potential application to horticulture. J Integr Plant Biol 49:1421-1434. doi:10.1111/j.1672-9072.2007. 00556.x

Costa JM, Ortuño MF, Lopes CM, Chaves MM (2012) Grapevine varieties exhibiting differences in stomatal response to water deficit. Funct Plant Biol 39:179-189. doi:10.1071/FP11156

Davies WJ, Wilkinson S, Loveys B (2002) Stomatal control by chemical signaling and the exploitation of this mechanism to increase the water use efficiency in agriculture. New Phytol 153:449-460

Davies WJ, Zhang J, Yang J, Dodd IC (2011) Novel crop science to improve yield and resource use efficiency in water-limited agriculture. J Agric Sci 149:123-131. doi:10.1017/S0021859610001115

De la Hera ML, Romero P, Gómez-Plaza E, Martínez A (2007) Is partial root-zone drying an effective irrigation technique to improve water use efficiency and fruit quality in field-grown wine grapes under 
semiarid conditions? Agric Water Manag 87:261-274. doi:10.1016/ j.agwat.2006.08.001

De Souza CR, Maroco JP, dos Santos TP, Rodrigues ML, Lopes CM, Pereira JS, Chaves MM (2003) Partial rootzone drying: regulation of stomatal aperture and carbon assimilation in field-grown grapevines (Vitis vinifera $\mathrm{cv}$. Moscatel). Funct Plant Biol 30:653-662. doi:10. 1071/FP02115

De Souza CR, Maroco JP, dos Santos TP, Rodrigues ML, Lopes CM, Pereira JS, Chaves MM (2005) Impact of deficit irrigation on water use efficiency and carbon isotope composition ( $813 \mathrm{C})$ of fieldgrown grapevines under Mediterranean climate. J Exp Bot 56: 2163-2172. doi:10.1093/jxb/eri216

Deng XP, Shan L, Zhang H, Turner NC (2006) Improving agricultural water use efficiency in arid and semiarid areas of China. Agric Water Manag 80:23-40. doi:10.1016/j.agwat.2005.07.021

Dobrowsky SZ, Pushnik JC, Zarco-Tejada PJ, Ustin SL (2005) Simple reflectance indices track heat and water stress-induced changes in steady-state chlorophyll fluorescence at canopy scale. Remote Sens Environ 97:403-414. doi:10.1016/j.rse.2005.05.006

Dokoozlian NK, Kliewer WM (1996) Influence of light on grape berry growth and composition varies during fruit development. J Am Soc Hortic Sci 121:869-874

Dos Santos T, Lopes CM, Rodrigues ML, Souza CR, Maroco J, Pereira JS, Silva JR, Chaves MM (2003) Partial rootzone drying: effects on growth and fruit quality of field-grown grapevines (Vitis vinifera). Funct Plant Biol 30:663-671. doi:10.1071/FP02180

Dos Santos T, Lopes CM, Rodrigues ML, Souza CR, Maroco J, Pereira JS, Silva JR, Chaves MM (2007) Effects of deficit irrigation strategies on cluster microclimate for improving fruit composition of 'Moscatel' field-grown grapevines. Sci Hortic 112:321-330. doi:10. 1016/j.scienta.2007.01.006

Downton WJS, Grant WJR, Loveys BR (1987) Diurnal changes in the photosynthesis of field grown grape vines. New Phytol 105:71-80. doi:10.1111/j.1469-8137.1987.tb00111.x

Dry PR, Loveys BR (1998) Factors influencing grapevine vigour and the potential for control with partial rootzone drying. Austr J Grape Wine Res 4:140-148. doi:10.1111/j.17550238.1998.tb00143.x

Dry PR, Loveys BR (1999) Grapevine shoot growth and stomatal conductance are reduced when part of the root system is dried. Vitis 38 : $151-156$

Dry PR, Loveys BR, During H (2000a) Partial drying of rootzone of grape. I. Transient changes in shoot growth and gas exchange. Vitis 39:3-7

Dry PR, Loveys BR, Stoll M, Steward D, McCarthy MG (2000b) Partial root zone drying - an update. Aust NZ Grapegrow Winemak. Annual technical Issue 35-39

Dry PR, Loveys BR, McCarthy MG, Stoll M (2001) Strategic irrigation management in Australian vineyards 1. Int Sci Vigne Vin 35:129 139

Du toit PG, Dry PR, Loveys BR (2003) A preliminary investigation on partial rootzone drying (PRD) effects on grapevine performance, nitrogen assimilation and berry composition. S Afr J Enol Vitic 24:43-54

Du T, Kang S, Zhang JB, Li F, Yan B (2008) Water use efficiency and fruit quality of table grape under alternate partial root-zone drip irrigation. Agric Water Manag 95:659-668. doi:10.1016/j.agwat. 2008.01.017

Düring H, Alleweldt G, Koch R (1978) Studies on hormonal control of ripening in berries of grape vines. Acta Hortic 80:397-405

Edwards EJ, Clingeleffer PR (2013) Inter-seasonal effects of regulated deficit irrigation on growth, yield, water use, berry composition and wine attributes of Cabernet Sauvignon grapevines. Aust J Grape Wine Res 19:261-276. doi:10.1111/ajgw.12027

Elmore CL, Donaldson DR, Smith RJ (1998) Weed management. In: Ingels CA (ed) Cover cropping in vineyards. Univ. California, Div Agr. Natural Resources, Publ. 3338, pp 107-112
Escalona JM, Flexas J, Medrano H (1999) Stomatal and non-stomatal limitations of photosynthesis under water stress in field-grown grapevines. Aust J Plant Physiol 26:421-433. doi:10.1071/PP99019

Escalona JM, Flexas J, Bota J, Medrano H (2003) Distribution of leaf photosynthesis and transpiration within grapevine canopies under different drought conditions. Vitis 42:57-64

Esteban MA, Villanueva MJ, Lissarrague JR (2001) Effect of irrigation on changes in the anthocyanin composition of the skin of $\mathrm{cv}$ Tempranillo (Vitis vinifera $\mathrm{L}$ ) grape berries during ripening. J Sci Food Agric 81:409-420. doi:10.1002/1097-0010(200103) 81:4<409::AID-JSFA 830>3.0.CO;2-H

Facelli JM, Pickett STA (1991) Plant litter: light interception and effects on an old-field plant community. Ecol 72:1024-1031. doi:10.2307/ 1940602

FAO (2014) Building a common vision for sustainable food and agriculture. Food and Agriculture Organization of the United Nations, Roma

Fernandes de Oliveira A, Mameli MG, de Pau L, Satta D, Nieddu G (2013) Deficit irrigation strategies in Vitis vinifera L. cv. Cannonau under Mediterranean climate. Part I-physiological responses, growth, yield and berry composition. S Afr J Enol Vitic 34:170-183

Flexas J, Escalona JM, Medrano H (1999) Water stress induces different levels of photosynthesis and electron transport rate regulation in grapevines. Plant Cell Environ 22:39-48. doi:10.1046/j.13653040.1999.00371.x

Flexas J, Bota J, Escalona JM, Sampol B, Medrano H (2002) Effects of drought on photosynthesis in grapevines under field conditions: an evaluation of stomatal and mesophyll limitations. Funct Plant Biol 29:461-471. doi:10.1071/PP01119

Flexas J, Ribas-Carbó M, Díaz-Espejo A, Galmés J, Medrano H (2008) Mesophyll conductance to $\mathrm{CO}_{2}$ : current knowledge and future prospects. Plant Cell Environ 31:602-621. doi:10.1111/j.1365-3040. 2007.01757.x

Flexas J, Galmés J, Gallé A, Gulias J, Pou A, Ribas-Carbo M, Tomàs M, Medrano H (2010) Improving water use efficiency in grapevines: potential physiological targets for biotechnologicalimprovement. Aust J Grape Wine Res 16:106-121

Flexas J, Barbour MM, Brendel O, Cabrera HM, Carriqui M, DíazEspejo A, Douthe C, Dreyer E, Ferrio JP, Gago J, Gallé A, Galmés J, Kodama N, Medrano H, Niinemets U, Pequero-Pina JJ, Pou A, Ribas-Carbó M, Tomás M, Tosens T, Warren CR (2012) Mesophyll diffusion conductance to $\mathrm{CO}_{2}$ : an unappreciated central player in photosynthesis. Plant Sci 193:70-84. doi:10.1016/j. plantsci.2012.05.009

Folorunso OA, Rolston DE, Prichard PT, Louie DT (1992a) Cover crops lower soil surface strength, may improve soil permeability. Calif Agric 46:26-27

Folorunso OA, Rolston DE, Prichard PT, Loui DT (1992b) Soil surface strength and infiltration rate as affected by winter cover crops. Soil Technol 5:189-197. doi:10.1016/0933-3630(92)90021-R

Fouquet R (2005) Les aquaporines de vigne: identification, études d'expression en conditions de contraintes abiotiques et approches de caractérisation fonctionnelle, Dissertation, University of Bordeaux I

Fourie JC (2011) Soil management in the Breede River Valley wine grape region, South Africa. 3. Grapevine performance. S Afr J Enol Vitic 32:60-70

Fourie JC, Louw PJE, Agenbag GA (2006) Cover crop management in a chardonnay/99 Richter vineyard in the coastal wine grape region, South Africa. 1. effect of two management practices on selected grass and broadleaf species. S Afric J Enol Vitic 27:167-177

Frederikson L, Skinkis PA, Peachey E (2011) Cover crop and floor management affect weed coverage and density in an establishing Oregon vineyard. Horttechnol 21:208-216

Fuentes S, De Bei R, Collins MJ, Escalona JM, Medrano H, Tyerman S (2014) Night-time responses to water supply in grapevines (Vitis 
vinifera L.) under deficit irrigation and partial root-zone drying. Agric Water Manag 138:1-9. doi:10.1016/j.agwat.2014.02.015

Gambetta GA, Fei J, Rost TL, Knipfer T, Matthews MA, Shackel KA, McElrone AJ (2013) Water uptake along the length of grapevine fine roots: developmental anatomy, tissue-specific aquaporin expression, and pathways of water transport. Plant Physiol 163:1254-1265. doi: 10.1104/pp. 113.221283

Gaudillère JP, Van Leeuwen C, Ollat N (2002) Carbon isotope composition of sugars in grapevine, and integrated indicator of vineyard water status. J Exp Bot 53:757-763. doi:10.1093/jexbot/53.369.757

Geerts S, Raes N (2009) Deficit irrigation as an on-farm strategy to maximize crop water productivity in dry areas. Agric Water Manag 96:1275-1284. doi:10.1016/j.agwat.2009.04.009

Ghaderi N, Talaie AR, Ebadi A, Lessani H (2011) The physiological response of three Iranian grape cultivars to progressive drought stress. J Agric Sci Technol 13:601-610

Gibberd MR, Walker RR, Blackmore DH, Condon AG (2001) Transpiration efficiency and carbon-isotope discrimination of grapevines grown under well-watered conditions in either glasshouse or vineyard. Aust J Grape Wine Res 7:110-117. doi:10.1111/j.17550238.2001.tb00197.x

Girona J, Mata M, del Campo J, Arbone's A, Bartra E, Marsal J (2006) The use of midday leaf water potential for scheduling deficit irrigation in vineyards. Irrigation Sci 24:115-127. doi:10.1007/s00271-005-0015-7

Göblyös J, Zanathy G, Donkó Á, Varga T, Bisztray G (2011) Comparison of three soil management methods in the Tokaj wine region. Mitt Klosterneuburg 61:187-195

Gómez-Alonso S, García-Romero E (2010) Effect of irrigation and variety on oxygen $\left(\delta^{18} \mathrm{O}\right)$ and carbon $\left({ }^{13} \mathrm{C}\right)$ stable isotope composition of grapes cultivated in a warm climate. Aust J Grape Wine Res 16:283-289. doi:10.1111/j.1755-0238.2009.00089.x

Gómez-del-Campo M, Ruiz C, Lissarrague JR (2002) Effect of water stress on leaf area development, photosynthesi, and productivity in Chardonnay and Airen grapevines. Am J Enol Viticult 53:138-143

Gómez-del-Campo M, Baeza P, Ruiz C, Lissarrague JR (2004) Waterstress induced physiological changes in leaves of four containergrown grapevine cultivars (Vitis vinifera L.). Vitis 43:99-105

Gómez-del-Campo M, Baeza P, Ruiz C, Sotes V, Lissarrague JR (2007) Effect of previous water conditions on vine response to rewatering. Vitis 46:51-55

Gregory PJ (2004) Agronomic approaches to increasing water use efficiency. In: Bacon MA (ed) Water use efficiency in plant biology. Blackwell Publishing Ltd., Oxford, pp 142-167

Greven M, Green S, Neal S, Clothier B, Neal M, Dryden G, Davidson P (2005) Regulated deficit irrigation (RDI) to save water and improve Sauvignon Blanc quality? Water Sci Technol 51:9-17

Gu S, Guoqiang D, Zoldoske D, Hakim A, Cochran R, Fugelsang K, Jorgensen G (2004) Effects of irrigation amount on water relations, vegetative growth, yield and fruit composition of Sauvignon blanc grapevines under partial root-zone drying and conventional irrigation in the San Joaquin Valley of California, USA. J Hortic Sci Biotechnol 79:26-33

Guerra B, Steenwerth K (2012) Influence of floor management technique on grapevine growth, disease pressure, and juice and wine composition: a review. Am J Enol Viticult 63:149-164. doi:10.5344/ajev. 2011.10001

Gulick SH, Grimes DW, Goldhamer DA, Munk DS (1994) Cover-cropenhanced water infiltration of a slowly permeable fine sandy loam. Soil Sci Soc 58:1539-1546. doi:10.2136/sssaj1994. $03615995005800050038 \mathrm{x}$

Hartwig NL, Ammon HU (2002) Cover crops and living mulches. Weed Sci 50:688-699. doi:10.1614/0043-1745(2002)050\%5B0688:AIACCA\% 5D2.0.CO;2

Hartwig NL, Hoffman LD (1975) Suppression of perennial legume and grass cover crops for notillage corn. Proc Northeast. Weed Sci Soc $29: 82-88$
Hatfield JL, Sauer TJ, Prueger JH (2001) Managing soils to achieve greater water use efficiency. Agron J 93:271-280. doi:10.2134/ agronj2001.932271x

Himelrick DG (1991) Growth and nutritional responses of nine grape cultivars tolow soil $\mathrm{pH}$. HortSci 26:269-271

Huber L, Porten M, Eisenbeis G, Rühl EH (2003) The influence of organically managed vineyard-soils on the phylloxera-populations and the vigor of grapevines. Acta Hortic 617:55-59

Ingels CA, Scow KM, Whisson DA, Drenovsky RE (2005) Effects of cover crops on grapevines, yield, juice composition, soil microbial ecology, and gopher activity. Am J Enol Viticult 56:19-29

Intrigliolo DS, Castel JR (2009) Response of Vitis vinifera cv. 'Tempranillo' to partial rootzone drying in the field: Water relations, growth, yield and fruit and wine quality. Agric Water Manag 96: 282-292. doi:10.1016/j.agwat.2008.08.001

Intrigliolo DS, Castel JR (2010) Response of grapevine cv. 'Tempranillo' to timing and amount of irrigation: water relations, vine growth, yield and berry and wine composition. Irrigation Sci 28:113-125. doi:10.1007/s00271-009-0164-1

Intrigliolo DS, Lakso AN (2011) Effects of light interception and canopy orientation on grapevine water status and canopy gas exchange. Acta Hortic 889:99-104

IPCC 2013, Stocker TF, Dahe Q, Plattner GK, Tignor M, Allen SK, Boschung J, Nauels A, Xia Y, Bex V, Midgley PM (2013) Climate change 2013: the physical science basis. Working group I contribution to the fifth assessment report of the intergovernmental panel on climate change. Cambridge University Press, Cambridge and New York

Jacobs SD (2014) Effect of rootstocks and water stress on gas exchange, water relations, and water use efficiency in petite Sirah grapevines. Dissertation, California State University

Jalota SK, Khera R, Chahal SS (2001) Straw management and tillage effects on soil water storage under field conditions. Soil Use Manag 17:282-287. doi:10.1111/j.1475-2743.2001.tb00039.x

Jeong ST, Goto-Yamamoto N, Kobayashi S, Esaka M (2004) Effects of plant hormones and shading on the accumulation of anthocyanins and the expression of anthocyanin biosynthetic genes in grape berry skins. Plant Sci 167:247-252. doi:10.1016/j.plantsci.2004.03.021

Jones HG (2004) Irrigation scheduling: advantages and pitfalls of plantbased methods. J Exp Bot 55:2427-2436. doi:10.1093/jxb/erh213

Jones HG, Vaughan RA (2010) Remote sensing of vegetation: principles, techniques, and applications. Oxford University Press, Oxford

Kaldenhoff R, Kolling A, Richter G (1993) A novel blue light-inducible and abscisic acid-inducible gene of Arabidopsis thaliana encoding an intrinsic membrane-protein. Plant Mol Biol 23:1187-1198. doi: 10.1007/BF00042352

Kaldenhoff R, Ribas-Carbo M, Flexas J, Lovisolo C, Heckwolf M, Uehlein N (2008) Aquaporins and plant water balance. Plant Cell Environ 31:658-666. doi:10.1111/j.1365-3040.2008.01792.x

Kang S, Zhang J (2004) Controlled alternate partial root-zone irrigation: its physiological consequences and impact on water use efficiency. $\mathrm{J}$ Exp Bot 55:2437-2446. doi:10.1093/jxb/erh249

Katerji N, Mastrorilli M, Ranab G (2008) Water use efficiency of crops cultivated in the Mediterranean region: review and analysis. Eur J Agron 28:493-507. doi:10.1016/j.eja.2007.12.003

Koundouras S, Tsialtas LT, Zioziou E, Nikolaou N (2008) Rootstock effects on the adaptive strategies of grapevine (Vitis vinifera L. cv. Cabernet Sauvignon) under contrasting water status: leaf physiological and structural responses. Agric Ecosyst Environ 128:86-96. doi: 10.1016/j.agee.2008.05.006

Koyama K, Sadamatsu K, Goto-Yamamoto N (2010) Abscisic acid stimulated ripening and gene expression in berry skins of the Cabernet Sauvignon grape. Funct Integr Genomics 10:367-381. doi:10.1007/s10142-009-0145-8

Kriedemann PE, Goodwin I (2003) Regulated deficit irrigation and partial rootzone drying. Land \& Water Australia, Canberra 
Lopes CM, Monteiro A, Rückert FE, Gruber B, Steinberg B, Schultz HR (2004) Transpiration of grapevines and co-habitating cover crop and weed species in a vineyard. A "snapshot" at diurnal trends. Vitis 43: $111-117$

Lopes CM, Santos TP, Monteiro A, Rodrigues M, Costa JM, Chaves MM (2011) Combining cover cropping with deficit irrigation in a Mediterranean low vigor vineyard. Sci Hortic 129:603-612. doi: 10.1016/j.scienta.2011.04.033

Loveys BR, Stoll M, Davies WJ (2004) Physiological approaches to enhance water use efficiency in agriculture: exploiting plant signaling in novel irrigation practice. In: Bacon $\mathrm{M}$ (ed) Water use efficiency in plant biology. Wiley-Blackwell, Oxford, pp 113-141

Lovisolo C, Perrone I, Hartung W, Schubert A (2008) An abscisic acidrelated reduced transpiration promotes gradual embolism repair when grapevines are rehydrated after drought. New Phytol 180: 642-651. doi:10.1111/j.1469-8137.2008.02592.x

Lovisolo C, Perrone I, Carra A, Ferrandino A, Flexas J, Medrano H, Schubert A (2010) Drought-induced changes in development and function of grapevine (Vitis spp.) organs and in their hydraulic and non-hydraulic interactions at the whole-plant level: a physiological and molecular update. Funct Plant Biol 37:98-116. doi:10.1071/ FP09191

Marguerit E, Brendel O, Lebon E, Van Leeuwen C, Ollat N (2012) Rootstock control of scion transpiration and its acclimation to water deficit are controlled by different genes. New Phytol 194:416-429. doi:10.1111/j.1469-8137.2012.04059.x

Maroco JP, Rodrígues ML, Lopes C, Chaves MM (2002) Limitations to leaf photosynthesis in field-grown grapevine under drought - metabolic and modelling approaches. Funct Plant Biol 29:451-459. doi: 10.1071/PP01040

Marsal J, Mata M, Del Campo J, Arbones A, Vallverdú X, Girona J, Olivo N (2008) Evaluation of partial root-zone drying for potential field use as a deficit irrigation technique in commercial vineyards according to two different pipeline layouts. Irrigation Sci 26:347-356. doi: 10.1007/s00271-007-0098-4

Matthews MA, Ishii R, Anderson MM, O’Mahony M (1990) Dependence of wine sensory attributes on vine water status. J Sci Food Agric 51:321-335. doi:10.1002/jsfa.2740510305

McCarthy MG (1997) The effect of transient water deficit on berry development of cv. Shiraz (Vitis vinifera L.). Austr J Grape Wine Res 3:2-8. doi:10.1111/j.1755-0238.1997.tb00128.x

McCarthy MG, Loveys BR, Dry PR (2002) Regulated deficit irrigation and partial rootzone drying as irrigation management techniques for grapevines. In: FAO (ed) Deficit irrigation practices. Water reports publication n. 22. FAO, Rome, pp 79-87

Medrano H, Escalona JM, Cifre J, Bota J, Flexas J (2003) A ten-year study on the physiology of two Spanish grapevine cultivars under field conditions: effects of water availability from leaf photosynthesis to grape yield and quality. Funct Plant Biol 30:607-619. doi:10. 1071/FP02110

Medrano H, Pou A, Tomás M, Martorell S, Escalona JM, Flexas J, Galmés J, Ribas-Carbó M, Gulías J (2010) Water use efficiency improvement in grapevines under Mediterranean conditions. Asp Appl Biol 105:47-55

Medrano H, Pou A, Tomás M, Martorell S, Gulias J, Flexas J, Escalona JM (2012) Average daily light interception determines leaf water use efficiency among different canopy locations in grapevine. Agric Water Manag 114:4-10. doi:10.1016/j.agwat.2012.06.025

Monteiro A, Lopes CM (2007) Influence of cover crop on water use and performance of vineyard in Mediterranean Portugal. Agric Ecosyst Environ 121:336-342. doi:10.1016/j.agee.2006.11.016

Monteiro A, Lopes CM, Machado JP, Fernandes N, Araújo A, Moreira I (2008) Cover cropping in a sloping, non-irrigated vineyard: IEffects on weed composition and dynamics. Ciência Téc Vitiv 23: 29-36
Mori K, Saito H, Goto-Yamamoto N, Kitayama M, Kobayashi S, Sugaya S, Gemma H, Hashizume K (2005a) Effect of abscísic acid treatment and night temperatures on anthocyanin composition in pinot noir grapes. Vitis 44:161-165

Mori K, Saito H, Goto-Yamamoto N, Kitayama M, Kobayashi S, Sugaya S, Gemma H, Hashizume K (2005b) Effect of abscísic acid treatment and night temperatures on anthocyanin composition in Pinot noir grapes. Vitis 44:161-165

Morison JIL, Baker NR, Mullineaux PM, Davies WJ (2008) Improving water use in crop production. Phil Trans R Soc B 363:639-658. doi: 10.1098/rstb.2007.2175

Morlat R (1987) Effects of different soil cultivation practices on the water consumption of grapevine and agronomic consequences. Agronomie 7:183-191

Moutinho-Pereira JM, Correia CM, Gonçalves BM, Bacelar EA, TorresPereira JM (2004) Leaf gas exchange and water relations of grapevines grown in three different conditions. Photosynthetica 42:8186. doi:10.1023/B:PHOT.0000040573.09614.1d

Myburgh PA (2003) Responses of Vitis vinifera L. cv. Sultanina to water deficits during various pre- and post-harvest phases under semi-arid conditions. S Afr J Enol Vitic 24:25-33

Naor A, Wample RL (1994) Gas exchange and water relations of field grown concord (Vitis Labruscana Bailey) grapevines. Am J Enol Viticult 45:333-337

Némethy L (2004) Alternative soil management for sandy vineyards. Acta Hortic 640:119-125

Nguyen TT, Fuentes S, Marschener P (2013) Effect of incorporated or mulched compost on leaf nutrient concentrations and performance for Vitis vinifera cv. Merlot J Soil Sci Plant Nutr 13:485-497. doi:10. 4067/S0718-95162013005000038

Nicholls CI, Parrella M, Altieri MA (2001) The effect of a vegetational corridor on the abundance and dispersal of insect biodiversity within a northern California organic vineyard. Landscape Ecol 16:133146. doi:10.1023/A:1011128222867

OIV (2009) Description des cépages du monde. OIV Ed., París

Padgett-Johnson M, Williams LE, Walker MA (2000) The influence of Vitis riparia rootstock on water relations and gas exchange of Vitis vinifera $\mathrm{cv}$. Carignane scion under non-irrigated conditions. Am J Enol Viticult 51:137-143

Padgett-Johnson M, Williams LE, Walker MA (2003) Vine water relations, gas exchange, and vegetative growth of seventeen Vitis species grown under irrigated and nonirrigated conditions in California. J Am Soc Hortic Sci 128:269-276

Patakas A, Kofidis G, Bosabalidis AM (2003a) The relationship between $\mathrm{CO}_{2}$ transfer mesophyll resistance and photosynthetic efficiency in grapevine cultivars. Sci Hortic 97:255-263. doi:10.1016/S03044238(02)00201-7

Patakas A, Stavrakas D, Fisarakis I (2003b) Relationship between $\mathrm{CO}_{2}$ assimilation and leaf anatomical characteristics in two grapevine cultivars. Agronomie 23:293-296. doi:10.1051/ agro:2003002

Patakas A, Noitsakis B, Chouzouri A (2005) Optimization of irrigation water use in grapevines using the relationship between transpiration and plant water status. Agric Ecosyst Environ 106:253-259. doi:10. 1016/j.agee.2004.10.013

Peppi MC, Fidelibus MW, Dokoozlian NK (2007) Application timing and concentration of abscisic acid affect the quality of 'Redglobe' grapes. J Hortic Sci Biotechnol 82:304-310

Pinamonti F (1998) Compost mulch effects on soil fertility, nutritional status and performance of grapevine. Nutr Cycl Agroecosyst 51: 239-248. doi:10.1023/A:1009701323580

Pongrácz DP, Beukman EF (1970) Comparative root anatomy of Vitis rootstocks. Agroplantae 2:83-94

Poni S, Lakso AN, Turner JR, Melious RE (1993) The effects of pre- and post- veraison water stress on growth and physiology of potted pinot noir grapevines at varying crop levels. Vitis 32:207-214 
Poni S, Bernizzoni F, Civardi S, Gatti M, PorroD CF (2009) Performance and water-use efficiency (single-leaf vs. whole-canopy) of wellwatered and half-stressed split-root Lambrusco grapevines grown in Po Valley (Italy). Agric Ecosyst Environ 129:97-106. doi:10. 1016/j.agee.2008.07.009

Pou A, Flexas J, Alsina MM, Bota J, Carambula C, De Herralde F, Galmés J, Lovisolo C, Jiménez M, Ribas-Carbo M, Rusjan D, Secchi F, Tomàs M, Zsófi Z, Medrano H (2008) Adjustments of water-use efficiency by stomatal regulation during drought and recovery in the drought-adapted Vitis hybrid Richter-110 (V. berlandieri $\mathrm{x}$ V. rupestris). Physiol Plant 134:313-323. doi:10. 1111/j.1399-3054.2008.01138.x

Pou A, Gulías J, Moreno MM, Tomás M, Medrano H, Cifre J (2011) Cover cropping in" Vitis vinifera" L. cv. Manto negro vineyards under Mediterranean conditions: effects on plant vigour, yield and grape quality. J Int Sci Vigne Vin 45:223-234

Pou A, Medrano H, Tomás M, Martorell S, Ribas-Carbó M, Flexas J (2012) An anisohydric grapevine variety performs better under moderate water stress and recovery than isohydric varieties. Plant Soil 359:335-349. doi:10.1007/s11104-012-1206-7

Prieto JA (2011) Simulation of photosynthesis and transpiration within grapevine (Vitis vinifera L.) canopies on a 3D architectural model application to training system evaluation. Dissertation, Université Montpellier

Prieto JA, Lebon E, Ojeda H (2010) Stomatal behavior of different grapevine cultivars in response to soil water status and air water vapour pressure deficit. J Int Sci Vigne Vin 44:9-20

Quick WP, Chaves MM, Wendler R, David M, Rodrigues ML, Passaharinho JA, Pereira JS, Adcock MD, Leegood RC, Stitt M (1992) The effect of water stress on photosynthetic carbon metabolism in 4 species grown under field conditions. Plant Cell Environ 15:25-35. doi:10.1111/j.1365-3040.1992.tb01455.x

Ripoche A, Metay A, Celette F, Gary C (2011) Changing the soil surface management in vineyards: immediate and delayed effects on the growth and yield of grapevine. Plant Soil 339:259-271. doi:10. 1007/s11104-010-0573-1

Rodrigues ML, Chaves MM, Wendler R, David MM, Quick WP, Leegood RC, Stitt M, Pereira JS (1993) Osmotic adjustment in water stressed grapevine leaves in relation to carbon assimilation. Aust J Plant Physiol 20:309-321. doi:10.1071/PP9930309

Rodrigues ML, Santos TP, Rodrigues AP, de Souza CR, Lopes CM, Maroco JP, Chaves MM (2008) Hydraulic and chemical signalling in the regulation of stomatal conductance and plant water use in field grapevines growing under deficit irrigation. Funct Plant Biol 35: 565-579. doi:10.1071/FP08004

Rogiers SY, Greer DH, Hutton RJ, Landsberg JJ (2009) Does night-time transpiration contribute to anisohydric behaviour in a Vitis vinifera cultivar? J Exp Bot 60:3751-3763. doi:10.1093/jxb/erp217

Rogiers S, Greer DH, Hutton RJ, Clarke SJ (2011) Transpiration efficiency of the grapevine cv. Semillon is tied to VPD in warm climates. Ann Appl Biol 158:106-114. doi:10.1111/j.1744-7348.2010.00446.x

Romero P, Fernández-Fernández JI, Cutillas A (2010) Physiological thresholds for efficient regulated deficit-irrigation management in winegrapes grown under semiarid conditions. Am J Enol Viticult 61:300-312

Romero P, Dodd IC, Martínez-Cutillas A (2012) Contrasting physiological effects of partial root zone drying in field-grown grapevine (Vitis vinifera L. cv. Monastrell) according to total soil water availability. J Exp Bot 63:4071-4083. doi:10.1093/jxb/ers088

Romero P, Muñoz R, Del Amor F, Valdes E, Fernández JI, MartinezCutillas A (2013) Regulated deficit irrigation based upon optimum water status improves phenolic composition in Monastrell grapes in wines. Agric Water Manag 121:85-101. doi:10.1016/j.agwat.2013. 01.007

Romero P, Pérez-Pérez JG, del Amor FM, Martinez-Cutillas A, Dodd IC, Botía P (2014) Partial root zone drying exerts different physiological responses on field-grown grapevine (Vitis vinifera $\mathrm{cv}$. Monastrell) in comparison to regulated deficit irrigation. Funct Plant Biol. doi:10. 1071/FP13276

Ross OC (2010) Reflective mulch effects on the grapevine environment, Pinot noir vine performance, and juice and wine characteristics. Dissertation, Lincoln University

Sadras VO (2009) Does partial root-zone drying improve irrigation water productivity in the field? A meta-analysis. Irrigation Sci 27:183190. doi:10.1007/s00271-008-0141-0

Santesteban LG, Miranda C, Royo JB (2009) Effect of water deficit and rewatering on leaf gas exchange and transpiration decline of excised leaves of four grapevine (Vitis vinifera L.) cultivars. Sci Hortic 121: 434-439. doi:10.1016/j.scienta.2009.03.008

Santesteban LG, Miranda C, Royo JB (2011) Regulated deficit irrigation effects on growth, yield, grape quality and individual anthocyanin composition in Vitis vinifera L. cv. 'Tempranillo'. Agric Water Manag 98:1171-1179. doi:10.1016/j.agwat.2011.02.011

Santos TP, Lopes CM, Rodrigues MC, de Souza CR, Maroco JP, Pereira JS, Silva JR, Chaves MM (2003) Partial root-zone drying: effects on growth and fruit quality of field-grown grapevines (Vitis vinifera). Funct Plant Biol 30:663-671. doi:10.1071/FP02180

Santos TP, Lopes CM, Rodrigues ML, de Souza CR, Ricardo-da-Silva JM, Maroco JP, Pereira JS, Chaves MM (2005) Effects of partial root-zone drying irrigation on cluster microclimate and fruit composition of field-grown Castelão grapevines. Vitis 44:117-125

Satisha J, Prakash GS, Venugopalan R (2006) Statistical modeling of the effect of physio-biochemical parameters on water use efficiency of grape varieties, rootstocks and their stionic combinations under moisture stress conditions. Turk J Agric For 30:261-271

Schultz HR (2003) Differences in hydraulic architecture account for nearisohydric and anisohydric behaviour of two field-grown Vitis viniferaL. cultivars during drought. Plant Cell Environ 26:13931405. doi:10.1046/j.1365-3040.2003.01064.x

Schultz HR, Stoll M (2010) Some critical issues in environmental physiology of grapevines: future challenges and current limitations. Aust J Grape Wine Res 16:4-24. doi:10.1111/j.1755-0238.2009.00074.x

Serra I, Strever A, Myburgh PA, Deloire A (2014) Review: the interaction between rootstocks and cultivars (Vitis vinifera L.) to enhance drought tolerance in grapevine. Aust J Grape Wine Res 20:1-14. doi:10.1111/ajgw.12054

Shanks LW, Moore DE, Sanders CE (1998) Soil erosion. In: Ingels CA, Bugg RL, McGourty GT, Christensen LP (eds) Cover cropping in vineyards. A Grower's handbook. Publication 3338. University of California, Oakland, pp 80-85

Shaw DA, Pittenger DR, McMaster M (2005) Water Retention and evaporative properties of landscape mulches. Proc.26th Annl. Irrigation Show, Phoenix, AZ, Nov. 6-8, 2005, pp 134-144

Sivilotti P, Bonetto C, Paladin M, Peterlunger E (2005) Effect of soil moisture availability on Merlot: from leaf water potential to grape composition. Am J Enol Viticult 56:9-18

Smart RE (1974) Photosynthesis by grapevine canopies. J App Ecol 11: 997-1006. doi:10.2307/2401759

Soar CJ, Speirs J, Maffei SM, Loveys BR (2004) Gradients in stomatal conductance, xylem sap ABA and bulk leaf ABA along canes of Vitis vinifera $\mathrm{cv}$. Shiraz: molecular and physiological studies investigating their source. Funct Plant Biol 31:659-669. doi:10.1071/FP03238

Sofo A, Nuzzo V, Tataranni G, Manfra M, De Nisco M, Scopa A (2012) Berry morphology and composition in irrigated and non-irrigated grapevine (Vitis viniferaL.). J Plant Physiol 169:1023-1031. doi:10. 1016/j.jplph.2012.03.007

Souza CR, Maroco JP, dos Santos TP, Rodrigues ML, Lopes C, Pereira JS, Chaves MM (2005) Control of stomatal aperture and carbon uptake by deficit irrigation in two grapevine cultivars. Agric Ecosyst Environ 106:261-274. doi:10.1016/j.agee.2004.10.014

Speirs J, Binney A, Collins M, Edwards E, Loveys B (2013) Expression of $\mathrm{ABA}$ synthesis and metabolism genes under different irrigation 
strategies and atmospheric VPDs is associated with stomatal conductance in grapevine (Vitis vinifera L. cv Cabernet Sauvignon). J Exp Bot 64:1907-1916. doi:10.1093/jxb/ert052

Steinmaus S, Elmore CL, Smith RJ, Donaldson D, Weber EA, Roncoroni JA, Miller PRM (2008) Mulched cover crops as an alternative to conventional weed management systems in vineyards. Weed Res 48:273-28. doi:10.1111/j.1365-3180.2008.00626.x

Stoll M, Loveys B, Dry P (2000) Hormonal changes induced by partial rootzone drying of irrigated grapevines. J Exp Bot 51:1627-1634. doi:10.1093/jexbot/51.350.1627

Tarara JM, Perez-Peña JE, Schreiner RP, Keller M, Smithyman P (2011) Net carbon exchange in grapevine canopies responds rapidly to timing and extent of regulated deficit irrigation. Funct Plant Biol 38:386-400. doi:10.1071/FP10221

Teasdale JR (1996) Contribution of cover crops to weed management in sustainable agricultural systems. J Prod Agric 9:475-479. doi:10. 2134/jpa1996.0475

Terry DB, Kurtural SK (2011) Achieving vine balance of syrah with mechanical canopy management and regulated deficit irrigation. Am J Enol Viticult 62(4):426-437

This P, Lacombe T, Thomas MR (2006) Historical origins and genetic diversity of wine grapes. Trends Genet 22:511-519. doi:10.1016/j. tig.2006.07.008

Thompson AJ, Andrews J, Mulholland BJ, McKee JMT, Hilton HW, Horridge JS, Farquhar GD, Smeeton RC, Smillie IRA, Black CR, Taylor IB (2007) Overproduction of abscisic acid in tomato increases transpiration efficiency and root hydraulic conductivity and influences leaf expansion. Plant Physiol 143:1905-1917. doi:10. 1104/pp. 106.093559

Thomson LJ, Hoffmann AA (2007) Effects of ground cover (straw and compost) on the abundance of natural enemies and soil macro invertebrates in vineyards. Agric For Entomol 9:173-179. doi:10. $1111 / j .1461-9563.2007 .00322 . x$

Tomás M, Medrano H, Pou A, Escalona JM, Martorell S, Ribas-Carbó M, Flexas J (2012) Water use efficiency in grapevine cultivars grown under controlled conditions: effects of water stress at the leaf and whole plant level. Aust J Grape Wine Res 18:164-172. doi:10.1111/ j.1755-0238.2012.00184.x

Tomás M, Flexas J, Copolovici L, Galmés J, Hallik L, Medrano H, Niinemets Ü (2013) Importance of leaf anatomy in determining mesophyll diffusion conductance to $\mathrm{CO} 2$ across species: quantitative limitations and scaling up by models. J Exp Bot 64:2269-2281. doi:10.1093/jxb/ert086

Tomás M, Medrano H, Brugnoli E, Escalona JM, Martorell S, Pou A, Ribas-Carbó M, Flexas J (2014a) Variability of mesophyll conductance in grapevine cultivars under water stress conditions in relation to leaf anatomy and water use efficiency. Aust J Grape Wine Res 20: 272-280. doi:10.1111/ajgw.12069

Tomás M, Medrano H, Escalona JM, Martorell S, Pou A, Ribas-Carbó M, Flexas J (2014b) Genetic variability in water use efficiency in grapevines. Environ Exp Bot 103:148-157. doi:10.1016/j. envexpbot.2013.09.003

Tramontini S, Vitali M, Centioni L, Schubert A, Lovisolo C (2013) Rootstock control of scion response to water stress in grapevine. Environ Exp Bot 93:20-26. doi:10.1016/j.envexpbot. 2013.04.001

Tyerman SD, Niemietz CM, Bramley H (2002) Plant aquaporins: multifunctional water and solute channels with expanding roles.
Plant Cell Environ 25:173-194. doi:10.1046/j.0016-8025.2001. 00791.x

Vandeleur RK, Mayo G, Shelden MC, Gilliham M, Kaiser BN, Tyerman SD (2009) The role of plasma membrane intrinsic protein aquaporins in water transport through roots: diurnal and drought stress responses reveal different strategies between isohydric and anisohydric cultivars of grapevine. Plant Physiol 149:445-460. doi:10.1104/pp.108.128645

Vicente-Serrano SM, Lopez-Moreno JI, Beguería S, Lorenzo-Lacruz J, Sanchez-Lorenzo A, García-Ruiz JM, Azorin-Molina C, MoránTejeda E, Revuelto J, Trigo R, Coelho F, Espejo F (2014) Evidence of increasing drought severity caused by temperature rise in Southern Europe. Environ Res Lett 9:044001. doi:10.1088/17489326/9/4/044001

Webb LB, Clingeleffer PR, Tyerman SD (2011) The genetic envelope of winegrape vines: potential for adaptation to future climate challenges. In: Yadav SS, Redden RJ, Hatfield JL, Lotze-Campen H, Hall AE (eds) Crop adaptation to climate change. Wiley-Blackwell, Oxford, pp 464-481

Wheeler SJ, Black AS, Pickering GJ (2005) Vineyard floor management improves wine quality in highly vigorous Vitis vinifera 'Cabernet Sauvignon' in New Zealand. N Z J Crop Hortic Sci 33:317-328. doi:10.1080/01140671.2005.9514365

Wheeler S, Loveys B, Ford C, Davies C (2009) The relationship between the expression of abscisic acid biosynthesis genes, accumulation of abscisic acid and the promotion of Vitis vinífera L. berry ripening by abscisic acid. Aust J Grape Wine Res 15:195-204. doi:10.1111/j. 1755-0238.2008.00045.x

Williams LE, Ayars JE (2005) Grapevine water use and the crop coefficient are linear functions of the shaded area measured beneath the canopy. Agric For Meteorol 132:201-211. doi:10.1016/j.agrformet. 2005.07.010

Williams LE, Matthews MA (1990) Grapevine. In: Stewart BJ, Nielsen DR (eds) Irrigation of agricultural crops. Agronomy monographs no. 30. ASA-CSSA-SSSA, Madison, pp 1019-1055

Williams LE, Grimes DW, Phene CJ (2010) The effects of applied water at various fractions of measured evapotranspiration on reproductive growth and water productivity of Thompson seedless grapevines. Irrigation Sci 28:233-243. doi:10.1007/s00271-009-0173-0

Winkel T, Rambal S (1993) Influence of water stress on grapevines growing in the field from leaf to whole plant response. Aust J Grape Wine Res 20:143-157. doi:10.1071/PP9930143

Winkler AJ, Cook JA, Kliewer WM, Lider LA (1974) General viticulture. University of California Press, Berkeley

Zhang J, Schurr U, Davies WJ (1987) Control of stomatal behaviour by abscisic acid which apparently originates in roots. J Exp Bot 38: 1174-1181. doi:10.1093/jxb/38.7.1174

Zhang G, Wang S, Li L, Inoue M, Xiang J, Qiu G, Jin W (2014) Effects of mulching and sub-surface irrigation on vine growth, berry sugar content and water use of grapevines. Agric Water Manag 143:1-8. doi:10.1016/j.agwat.2014.05.015

Zsófi Z, Gál L, Szilágy Z, Szücs E, Marschall M, Nagy Z, Bálo B (2009) Use of stomatal conductance and pre-dawn water potential to classify terroir for the grape variety Kékfrankos. Aust J Grape Wine Res 15:36-47. doi:10.1111/j.1755-0238.2008.00036.x

Zufferey V, Murisier F, Schultz HR (2000) A model analysis of the photosynthetic response of Vitis vinifera L. cvs. Riesling and chasselas leaves in the field: I. Interaction of age, light and temperature. Vitis 39:19-26 